\title{
Occupational heat stress under high-heat furnace work environments - a comprehensive review on developing countries
}

\author{
Milap SHARMA ${ }^{1 *} \odot$, Sarfaraz ALAM $^{2} \odot$, Narendra MOHAN SURI ${ }^{1} \oplus$, Suman KANT $^{1} \oplus$ \\ ${ }^{1}$ Department of Production and Industrial Engineering, Punjab Engineering College, Chandigarh, India \\ ${ }^{2}$ Department of Design, Indian Institute of Technology Guwahati, Assam, India
}

\section{ARTICLE INFO}

\section{Article history}

Received: 04 February 2021

Accepted: 01 October 2021

\section{Keywords:}

Furnace Work, High-heat

Environment, Workers,

Heat Strain, Assessment,

Harmful Impacts

\begin{abstract}
In developing countries, workers' employed under high-heat furnace work environments are exposed to severe heat stress; an ignored occupational health hazard especially under the unorganized work-sectors. During hot summer season, lot of underprivileged workers are strained by harsh thermal work-conditions with subsequent health challenges, declining their productivity and attributes to financial burden. As compared to developed countries, absence of adequate regulatory guidelines and control policies increases the risk-severity under the rampant conditions. The aim of the present study is to gain insights on the prevalence of occupational heat-stress under high-heat furnace work environments with special reference to developing countries. Present review study recognizes the prevalent issues by summarizing the dominant heat-stress factors (environmental, individual, and physiological), suitable assessment strategies, and consequent negative impacts on health and productivity followed by encapsulation of related heat-stress assessment studies particularly from the developing countries. From the assessment studies, it's evident that the predominant chronic heat-stress adversely impacts the workers' health and accompanying performance loss. Apart from heat related morbidities, severe health impacts such as immunological suppression, renal/urologic anomalies, and sub-cellular DNA damage are also attributable to this occupational health hazard. The prevalent thermal work-conditions necessitates implementation of adequate preventive measures and control policies to ameliorate the workers' productive capacity and social well-being. Remedial control interventions like proper ventilation design, installing reflective thermal protective shields, providing cooling spots, optimized cooling vest design, and sensor based intelligence may be considered as an effective control measures with emphasis on ameliorating the heat stress exposure under high-heat furnace work environments.
\end{abstract}

Cite this article as: Milap S, Sarfaraz A, Narendra M S, Suman K. Occupational heat stress under high-heat furnace work environments - a comprehensive review on developing countries. J Ther Eng 2021;7(8):2068-2092.

\footnotetext{
${ }^{*}$ Corresponding author.

*E-mail address: milapsharma25@gmail.com

This paper was recommended for publication in revised form by Regional Editor

Baha Zafer
} 


\section{INTRODUCTION}

In developing countries, heat stress is often an unacknowledged occupational health hazard $[1,2]$. Excessive hot environments are usually wide-spread in foundries, iron and steel industries, glass manufacturing units, rubber processing, coke ovens, mining sites, and several other industrial sectors $[2,3]$. Heat stress impacts the human physiological mechanism in terms of change in heart rate, skin temperature, core body temperature, and body mass loss due to sweating and further impose suppressions on users' health and work productivity [4]. As compared to developed countries, workers employed in the micro small and medium enterprises (MSME) sector are mostly uneducated and unaware of this occupational health hazard where poverty also plays a vital role. Most industries falling under the MSME sector are highly labour intensive due to lack of modernistic equipment's and not much concerned about labour's health and safety. In developing countries, less information is available on the combined effect of workplace heat exposure and climatic conditions $[1-3,5]$. Climatic zones like tropical and subtropical regions having higher ambient temperature and humidity values may impose greater risk of heat-related illness and safety threats among workers' employed in developing countries, having low and medium source incomes [5-8].
A prolonged period of heat exposure could results in consequent performance loss among workers; particularly functioning in an indoor high heat work-environment and negatively impacts their productive capacity [9-11]. The aim of the present work is to gain insights on the factors affecting the heat stress exposure among workers employed in furnace work-sectors, available ISO standards, and suitable heat stress assessment strategies being widely used for such hot work environments. Moreover, various physiological parameters as an effective indicators of heat strain have also been addressed. Present work also summarizes several heat stress assessment studies (conducted by researchers around the globe; particularly in developing countries) related to high-heat work environments in a rigorous manner during the past two decades. The influence of occupational heat stress on workers' productivity, negative health impacts, and role of design interventions in ameliorating hot stressful conditions have also been taken into consideration in a novel systematic approach. In present approach, relevant articles and publications have been searched from leading literature databases i.e. Scopus, PubMed, Science direct, and Google scholar. For searching strategy, several keywords like heat stress, heat strain, hot work environments, heat exposure, furnace, foundry, worker health and safety have been used. From identified literature studies, relevant articles

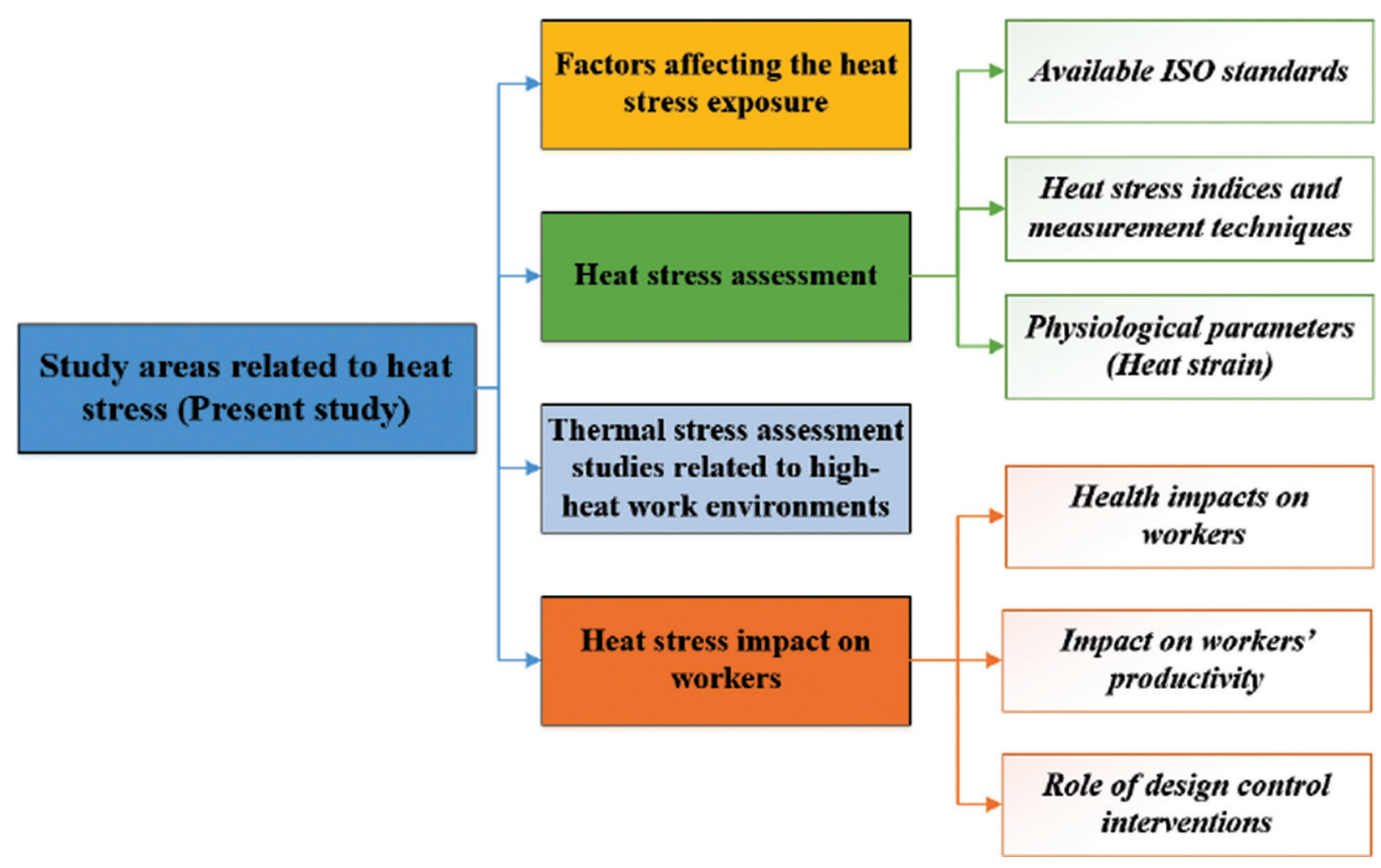

Figure 1. Work flowchart for the present literature study. 


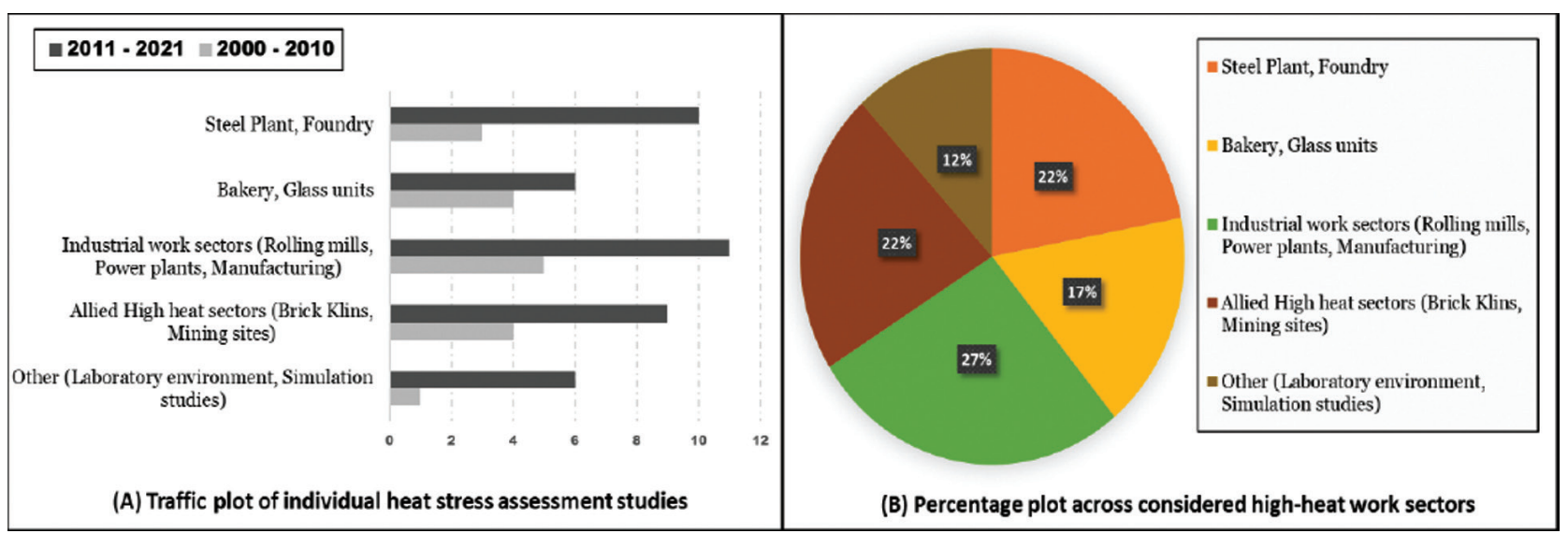

Figure 2. Summary of the thermal stress assessment in the individual studies.

associated with the concerned field were sorted out. The effective literature roadmap for the present work have been described briefly in Figure 1. Also, Figure 2 summarizes the considered thermal assessment studies related to different high heat work sectors like steel plants, foundries, rolling mills, manufacturing sector, glass manufacturing units, bakeries, brick kilns, mining sites, and also laboratory based environment studies.

Present review study would be beneficial for occupational health practitioners, industrialists, and policy makers (particularly in developing countries) in analysing the prevalent hot stressful conditions under high heat work sectors and providing pathway to reduce occupational heat stress exposures upto the desired permissible limits.

\section{FACTORS AFFECTING THE HEAT STRESS EXPOSURE}

There are six main agents that accord to the heat stress exposure experienced by the user under hot stressful work conditions like furnace environment. These six factors includes four environmental (air temperature, radiant temperature, air speed and relative humidity) and two individual factors (physical work activity and clothing worn) [12]. There are other personal factors like gender, age, psychosocial factors, health issues and poor habits (consumption of alcohol, tobacco) which also contributes to this occupational health hazard $[2,6]$. Furnace is considered as a dominant source of radiant heat. The radiant and convective heat gains by the workers close to the furnace combined with climatic conditions leads to several heat related disorders like heat rashes, cramps, dehydration, exhaustion, and even heat stroke [13]. In furnace work industries, the temperature range widely depends on the type of work operation. Table 1 describes the furnace temperature range (in degree Celsius) for such different work-sectors.
Table 1. Furnace temperature range for different worksectors

\begin{tabular}{ll}
\hline Work-Sector & $\begin{array}{l}\text { Furnace Temperature Range } \\
\text { (in degree Celsius) }\end{array}$ \\
\hline Glass Industry $[14,15]$ & $1400^{\circ} \mathrm{C}$ to $1600^{\circ} \mathrm{C}$ \\
Rolling Mill Furnace $[16,17]$ & Upto $1200^{\circ} \mathrm{C}$ \\
Blast Furnace $[18,19]$ & $1500^{\circ} \mathrm{C}$ to $1650^{\circ} \mathrm{C}$ \\
Electric Arc Furnace [20] & Upto $1800^{\circ} \mathrm{C}$ \\
Induction Furnace [21-23] & $1560^{\circ} \mathrm{C}$ to $1650^{\circ} \mathrm{C}$ \\
Bakery Oven $[24,25]$ & $90^{\circ} \mathrm{C}$ to $260^{\circ} \mathrm{C}$; upto $480^{\circ} \mathrm{C}$ \\
Brick Kilns $[26,27]$ & $900^{\circ} \mathrm{C}$ to $1200^{\circ} \mathrm{C}$ \\
\hline
\end{tabular}

\section{Environmental and Personal Factors}

Air temperature is one of the main factor of importance (Figure 3) while considering heat stress, which represents the workers' surrounding air temperature. The other important environmental factor of concern is radiant temperature as furnace is a dominant source of radiant heat. Radiant and convective heat gain by the workers close to the furnace leads to heat disorders. Radiant temperature is much more influential than air temperature for a furnace work environment, as it greatly affects the heat exchange mechanism of worker with its surroundings. Another factor, which influence the heat exchange mechanism is humidity; we generally consider relative humidity $(\mathrm{RH})$ which is the ratio of actual amount of water vapor present to the maximum quantity in the air at that temperature. $\mathrm{RH}$ varies considerably for an indoor work environment and is of great importance as a higher humid work environment would prevent the sweat evaporation from the skin surface which would results in increase of worker's core body temperature (CBT). Also, air velocity corresponds to the air flow surrounding the worker 
and is one another influential factor desirable for relieving heat stress in a furnace work environment. Still air results in heating up of the work environment, whereas moving air supports heat loss by convection and similarly physical movement of the workers results in increase of air flow, but depends on the activity level $[12,28]$.

Being warm blooded creatures, our body generates heat continuously and the rate at which this heat is generated is given in terms of "metabolic rate". Usually it depends on the activity of the worker and given in terms of "met", ( 1 met = $58.2 \mathrm{~W} / \mathrm{m}^{2}$ ) [28]. Metabolic rate depends on different physical characteristics of a person and the level of muscular work intensity level (ISO 9886, 2004). Most of the previous research studies have classified the metabolic rate for highheat furnace related work operations under moderate and heavy workload categories [6, 14-16, 27, 29, 30]. ISO 8996 standard provides a detailed estimation of the same based on different parameters like heart rate, weight, body mass index (BMI) and classifies work category (low, moderate, high) based on the metabolic rate [31]. Metabolic rate varies significantly for different type of activities (like resting, sedentary, standing, domestic work, industrial work) and is different from person to person. Metabolic heat (in W) is evaluated from the metabolic rate by multiplying it with the body surface area (in $\mathrm{m}^{2}$ ). Du Bois provides one such estimation to calculate the body surface area and suggests it varies from $1.3 \mathrm{~m}^{2}$ to $2.2 \mathrm{~m}^{2}$; whereas for an average adult it is considered as $1.8 \mathrm{~m}^{2}$ [32]. Suppose a furnace worker with average surface area equal to $1.8 \mathrm{~m}^{2}$, performing a moderate level work activity (2.0 met); will be producing metabolic heat equal to $(58.2 \times 2.0 \times 1.8) 209.52 \mathrm{~W}$. Metabolic rate has a critical impact on the workers thermal comfort; as furnace work has been classified as moderate to high level work. As more heat is produced and it needs to be dissipated, so that the body's inner temperature doesn't exceeds the permissible limit values.

The other important personal factor is the clothing worn; providing insulation effect which gives resistance to heat transfer. If the insulation level of clothing is too high, then it will generate immense heat stress even if the work conditions are not very hot. It is represented in terms of "clo", where 1 clo corresponds to $0.155 \mathrm{~m}^{2}{ }^{\circ} \mathrm{C} / \mathrm{W}$ [33]. Clothing factor is of great concern particularly in work conditions similar to furnace industries, as it affects the sweating rate which in turns imbalances the body heat exchange mechanism, especially when personal protective equipment (PPE) is worn by the worker [34]. But on the other side, it also protects the worker in cold environments and mainly depends on the actual work conditions. ISO 9920 standard provides an estimation of thermal insulation values for various clothing ensembles (in "clo") and vapor permeability resistance; which in turns impacts the thermal strain experienced by the worker under respective work-conditions [33]. However, few other personal factors which are not directly related, but research studies revealed that factors like psychological ability, age, gender, health conditions, and other poor work practices also contributes to the thermal discomfort [2-7]. Table 2 describes the considered metabolic rate and clothing insulation values in related thermal assessment studies under different work environments.

The heat exchange between the human and its surroundings has been represented by heat balance equation which relates the heat production rate to rate of heat lost. The combined heat loss by radiation, convection and conductions

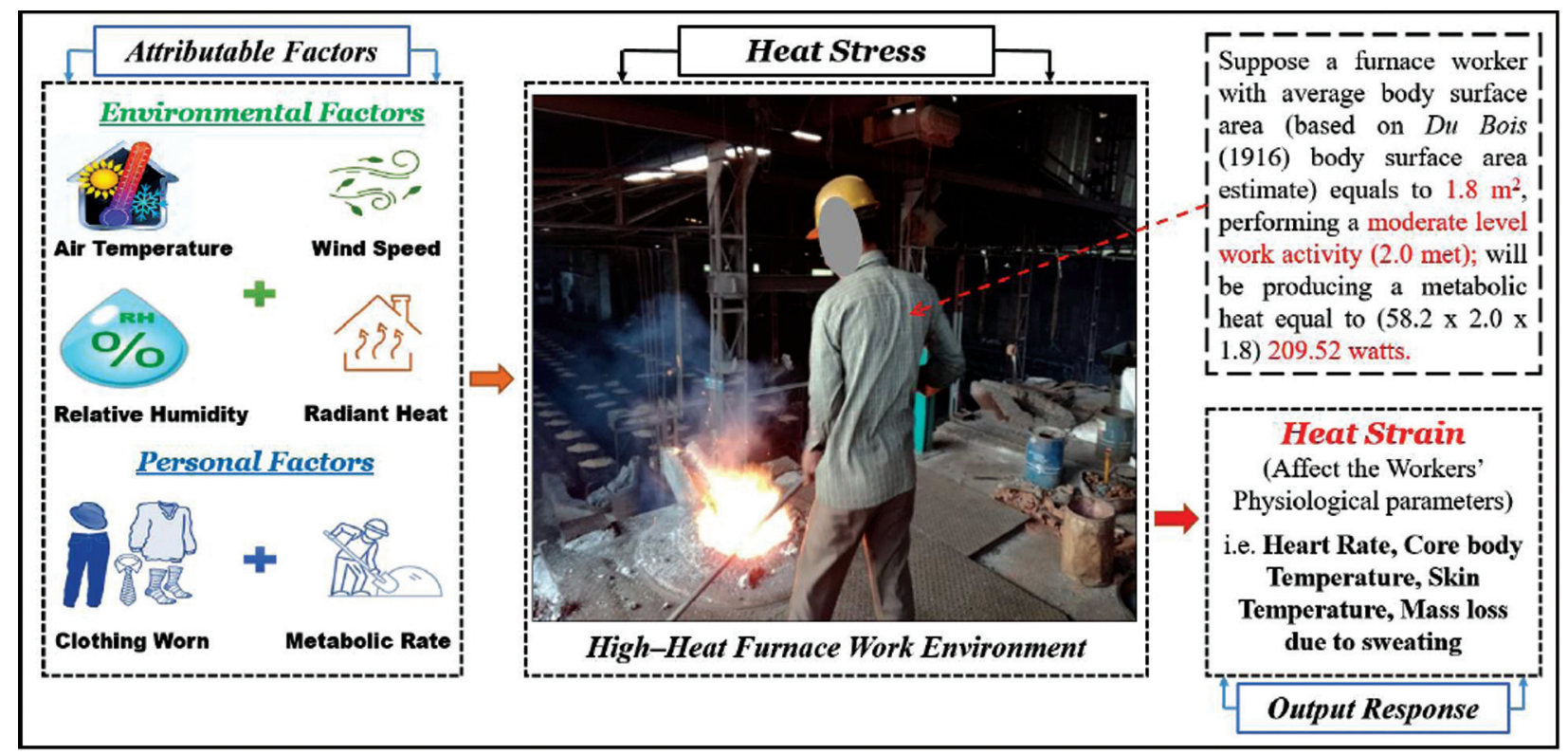

Figure 3. Dominant factors for Heat Stress under high-heat work environment. 
Table 2. Metabolic rate and clothing insulation values considered in related work-studies

\begin{tabular}{|c|c|c|c|c|c|}
\hline First Author & Work environment & Location & Metabolic rate & Activity level & $\begin{array}{l}\text { Clothing } \\
\text { Insulation (clo) }\end{array}$ \\
\hline Srivastava et al. [15] & Glass industry & India & $200-350 \mathrm{kcal} / \mathrm{h}$ & Moderate & NS \\
\hline Pourmahabadian et al. [14] & Glass industry & Iran & $200-350 \mathrm{kcal} / \mathrm{h}$ & Moderate & NS \\
\hline Ayyappan et al. [35] & $\begin{array}{l}\text { Automotive } \\
\text { Industry }\end{array}$ & Chennai, India & NS & Light to moderate & 0.6 \\
\hline Giahi et al. [18] & Steel industry & Western Iran & $130-200 \mathrm{~W} / \mathrm{m}^{2}$ & Light to moderate & NS \\
\hline Hajizadeh et al. [27] & Brick kiln & Iran & $415 \mathrm{~W} / \mathrm{m}^{2}$ & Heavy & 0.6 \\
\hline Krishnamurthy et al. [6] & Steel industry & Southern India & NS & Heavy & $\begin{array}{l}0.6 \text { (work uniform) } \\
2.0 \text { (aluminum PPE) }\end{array}$ \\
\hline Yang et al. [36] & Industrial power plant & Tainan, Taiwan & $154-313 \mathrm{~W} / \mathrm{m}^{2}$ & Moderate & 0.6 \\
\hline Fahed et al. [29] & Steel plant & $\begin{array}{l}\text { Karabuk city, } \\
\text { Turkey }\end{array}$ & NS & Heavy & 0.8 \\
\hline Mohammadian et al. [16] & Rolling industry & Tehran, Iran & $140-295 \mathrm{~W} / \mathrm{m}^{2}$ & Moderate & NS \\
\hline Rabeiy [37] & Bakeries & Assiut city, Egypt & $200-260 \mathrm{~W} / \mathrm{m}^{2}$ & Moderate & NS \\
\hline Zare et al. [38] & Mining sites & $\begin{array}{l}\text { South-eastern, } \\
\text { Iran }\end{array}$ & $100-160 \mathrm{~W} / \mathrm{m}^{2}$ & Light to moderate & NS \\
\hline Jafari et al. [30] & Foundry & Tehran, Iran & $200-350 \mathrm{kcal} / \mathrm{h}$ & Moderate & NS \\
\hline
\end{tabular}

NS: Not specified

accounts for around $72 \%$ of the total heat loss rate [28]. The heat balance equation is described in equation (3).

$$
H P R=M-W_{E}
$$

Where, "HPR" is heat production rate $\left(\mathrm{W} / \mathrm{m}^{2}\right)$, " $\mathrm{M}$ " is total rate of energy production $\left(\mathrm{W} / \mathrm{m}^{2}\right), " \mathrm{~W}_{\mathrm{E}}$ " is external work $\left(\mathrm{W} / \mathrm{m}^{2}\right)$

$$
H L R=R+C+E+L+K+S
$$

Where, "HLR" is heat loss rate, "R" represents heat lost by radiation, "C" is convection thermal loss (natural and forced), " $E$ " is evaporative loss (sweating), "L" is heat loss due to warm and wet air which is inhaled and exhaled, " $\mathrm{K}$ " is heat lost by conduction, " $\mathrm{S}$ " is body heat storage rate. The heat balance between the subject and its work place exists, when heat production rate is equal to heat loss rate.

$$
M-W_{E}=R+C+E+L+K+S
$$

Workers employed under hot and harsh thermal environments like furnace work operations are generally prone to acclimatization; which is getting used to the habitual work environment. Acclimatization is generally achieved within a period of one to two weeks (while working for at least 1 hour each day in such hot work environment) [39, 40]. Acclimatized workers have physiological adjustments to their body, like increase in sweat glands capacity (more sweating occurs to evaporate the heat which cools the body), decrease in heart rate and core body temperature as compared to non-acclimatized workers [40]. So, acclimatization results in increase of the worker's tolerance ability in response to heat stress. However, discontinuation of worker's heat exposure results in rolling back to the unacclimatized state in a few weeks. Generally, unacclimatized workers are newly recruited workforce or old workers who have been absent from work (due to health issues or leave) for a period of fourteen days.

\section{HEAT STRESS ASSESSMENT}

For heat stress assessment, several indices have been developed over the past century which includes the environmental factors and personal factors or combination of both [41]. There are several indices which include the physiological parameters (heart rate (HR), skin temperature $\left(\mathrm{T}_{\mathrm{sk}}\right)$, body mass loss due to sweating, core body temperature) into consideration. Parsons [34] suggested a three step approach which involves ISO 7243 standard for direct assessment based on monitoring and control of hot environments; ISO 7933 (rational indices approach) for analysing the heat exchange between the worker and its surroundings followed by ISO9886 standard that describes the principles of physiological measurement which may be used in the establishment of personal monitoring systems of workers exposed to hot environments. This three step approach could be beneficial in conducting more in-depth analysis of the hot work conditions to which the workers are exposed; by considering the effect of environmental 
factors, metabolic rate, clothing insulation, sweat evaporation and physiological variables.

\section{Suitable ISO Standards}

There are several ISO standards (with recent modifications) available which are suitable for evaluating heat stress parameters in hot and humid work environments; as depicted in Table 3. ISO 7243 provides an initial screening or heat stress exposure assessment for hot work environment. To validate the screening results, physiological parameters can be evaluated based on the ISO 9886 standard. For more in-depth analysis ISO 7933 must be used, which provides better estimation of the thermal strain experienced by the worker [34]. There are also two supporting standards i.e. ISO 9920 and ISO 8996, which provides thermal insulation values for different types of clothing worn and metabolic rate based on the physical work activity performed.

\section{Heat Stress Indices for Hot and Humid Work Environment}

Heat stress indices can be divided into three main categories i.e. rational indices (based on the heat exchange equation), empirical indices (relating to objective and subjective strain) and direct indices (involving direct measurements) [46]. Based on research studies, several heat stress indices that have been found suitable for monitoring and evaluating the thermal stress conditions under high-heat work environments, which are described as:

Wet Bulb Globe Temperature (WBGT): WBGT is an empirical index; widely used and validated index for the assessment of heat stress in hot work environments considering the combined effects of air temperature, humidity, air velocity and radiation by measuring natural wet-bulb temperature $\left(\mathrm{T}_{\mathrm{nw}}\right)$, dry bulb temperature $\left(\mathrm{T}_{\mathrm{a}}\right)$ and radiant effects using globe temperature $\left(\mathrm{T}_{\mathrm{g}}\right)$; in degree Celsius for both indoor and outdoor work conditions. Equation (4) and (5) shows the respective expressions without and with solar load effect [46].

For Indoor work environment;

$$
W B G T=0.7 T_{n w}+0.3 T_{g}
$$

For outdoor environment;

$$
W B G T=0.7 T_{n w}+0.2 T_{g}+0.1 T_{a}
$$

Table 3. ISO Standards suitable for evaluating heat stress parameters in hot and humid work environments

\begin{tabular}{lll}
\hline ISO Standard & Description & Evaluated Parameters \\
\hline ISO7243:2017 [42] & It provides a method for the assessment of heat stress in hot & For Indoor environment; \\
& work environments considering the effect of radiant temperature & $W B G T=0.7 T_{n w}+0.3 T_{g}$ \\
& using Globe temperature $\left(\mathrm{T}_{\mathrm{g}}\right)$, natural wet bulb temperature $\left(\mathrm{T}_{\mathrm{nw}}\right)$ & For outdoor environment; \\
& and ambient air temperature $\left(\mathrm{T}_{\mathrm{a}}\right)$. The modified standard also & \\
& includes the combined effects of clothing-worn and metabolic & WBGT $=0.7 T_{n w}+0.3 T_{g}+0.1 T_{a}$ \\
& rate classifications based on the work-activity performed; and \\
& also provides the work rest cycle for a task based on the ACGIH \\
& guidelines.
\end{tabular}

ISO 9886:2004 [43] This standard explains different measurement techniques for indicators of several physical parameters like heart rate, skin temperature, Body mass loss due to sweating and core body temperature characterizing the respective thermal environments.

ISO 7933:2004 [45] It evaluates the thermal stress experienced by a subject in a hot and humid work conditions. It gives a prediction of the sweat rate and the internal core temperature (as indicators of thermal strain), it provides a computer based program for the evaluation of predicted heat strain (PHS) model.

ISO 8996:2004 [31]

ISO 9920:2007 [33] them under "Low, Moderate, High and Very-High workloads".
This standard provides different methods for the determination Metabolic Rate $\left(\mathrm{W} / \mathrm{m}^{2}\right)$ of metabolic rate for different work tasks/activities, work cycles in the context of various climatic working environment; categorizing

Heart Rate, Skin Temperature, Core Body Temperature, Body mass loss (sweating)

Required Sweat Rate, Maximum Sweat Rate, Predicted core body temperature, Thermal strain of various clothing ensembles (in terms of "clo") like thermal insulation and water vapor resistance; which in turns effect the thermal strain experienced by the subject with respect to the working conditions. 
ISO 7243 standard also considers the spatial and temporal variations as given in equations (6) and (7) by evaluating the WBGT w.r.t three different heights levels like ankle height $(0.1 \mathrm{~m})$, waist height $(1.1 \mathrm{~m})$ and head height $(1.7 \mathrm{~m})$ and also based on the different time intervals using time weighted average formula. It also takes into account the effect of clothing ensembles worn by the workers in terms of clothing adjustment values (CAV) and classifies the physical work activity of the workers based on the metabolic rate (resting, low metabolic rate, moderate, high, or very high metabolic rate). These adjustments provide the effective WBGT index reference values (threshold limit values (TLVs)) for acclimatized and non-acclimatized workers based on the physical activity [42].

$$
\begin{gathered}
W B G T_{\text {Spatial }}=\left[W B G T_{\text {Head }}+\right. \\
\left.\left(2 \times W B G T_{\text {Waist }}\right)+W B G T_{\text {Ankle }}\right] / 4 \\
W B G T_{T W A}=\left[\left(W B G T_{1} \times T_{1}\right)+\left(W B G T_{2} \times T_{2}\right)+\right. \\
\left.\cdots \cdots+\left(W B G T_{n} \times T_{n}\right)\right] /\left(T_{1}+T_{2}+\cdots \cdots T_{n}\right)
\end{gathered}
$$

Physiological Strain Index (PSI): PSI is an empirical heat stress index that indicates the physiological strain experienced by a person in a hot environment by evaluating two physiological parameters [47] i.e. rectal temperature $\left(\mathrm{T}_{\mathrm{re}}\right)$ and heart rate (HR). It indicates the physiological strain based on a 10 point universal scale (with PSI values varying from 0 to 10) and respective thermal strain level as follows; 0 - 2 (No/little), 3- 4 (low), 5 - 6 (Moderate), 7 - 8 (High), and $9-10$ (Very High). It considers the combined effect of both thermoregulatory and cardiovascular system, while evaluating the thermal strain. The physiological strain index is expressed by equation (8):

$$
\begin{aligned}
P S I= & 5\left(T_{r e_{t}}-T_{r e_{0}}\right) \times\left(39.5-T_{r e_{0}}\right)^{-1} \\
& +5\left(H R_{t}-H R_{0}\right) \times\left(180-H R_{0}\right)^{-1}
\end{aligned}
$$

Where; $\mathrm{T}_{\text {ret }}$ is simultaneous rectal temperature measurement taken at any time $\left(\right.$ in $\left.{ }^{\circ} \mathrm{C}\right)$

$\mathrm{T}_{\mathrm{re} 0}$ is the initial rectal temperature measurement $\left(\right.$ in $\left.{ }^{\circ} \mathrm{C}\right)$

$\mathrm{HR}_{\mathrm{t}}$ is the simultaneous heart rate measurement taken at any time (in bpm)

$\mathrm{HR}_{0}$ is the initial heart rate measurement (in bpm)

Based on the PSI index, the maximum allowable rise in rectal temperature during heat exposure is $3^{\circ} \mathrm{C}\left(36.5^{\circ} \mathrm{C}\right.$ to $39.5^{\circ} \mathrm{C}$ ) and maximum allowable elevation for heart rate (HR) is $120 \mathrm{bpm}$ (60 to $180 \mathrm{bpm}$ ). PSI can be evaluated for any time of exposure, while a user is performing any work task or at rest/recovery period, as it involves the measurement of only two physiological parameters, which reduces the scope of error [48].
Discomfort Index (DI): The development of a direct indices tool called the "discomfort index" based on dry bulb temperature $\left(\mathrm{T}_{\mathrm{d}}\right)$ and wet bulb temperature $\left(\mathrm{T}_{\mathrm{w}}\right)$ in ${ }^{\circ} \mathrm{F}$; with some correction factor relates the thermal degree of discomfort perceived by the user in a work environment [49]. Higher the value of DI results in higher degree of discomfort. The different levels of discomfort are given as: DI $>70$ (people feel discomfort), DI > 75 (over half of the population will feel uncomfortable), when DI $=79$ (everyone will be uncomfortable), and DI $\geq 80$ (discomfort becomes more serious). The Discomfort Index is given in equation (9) followed by the cumulative discomfort index [50] in equation (10).

$$
\begin{gathered}
D I=0.4\left(T_{d}+T_{w}\right)+15 \\
D I=0.5\left(T_{d}+T_{w}\right)
\end{gathered}
$$

Heat stress index (HSI): HSI (proposed by Belding and Hatch, 1955) evaluates the heat stress in a hot and humid work environment based on the heat exchange equation between the human and its surroundings [51]. HSI evaluates the heat strain experienced by the user in a thermal work environment based on the evaluation of metabolic rate $(M)$, radiant load $(R)$, convective load $(C)$, and maximum evaporative cooling (E). HSI provides a single value which indicates the heat strain level experienced by the user in a thermal environment [52]. The Heat Stress Index (HSI) equation is given by equation (11):

$$
H S I=\left(\frac{E_{\text {req }}}{E_{\text {max }}}\right) \times 100
$$

Where:

$$
\begin{gathered}
E_{r e q}=M-(C+R) \\
E_{\max }=E
\end{gathered}
$$

Convective heat exchange

$$
(\mathrm{C})=7.0 \times V^{0.6} \times\left(T_{\text {air }}-T_{\text {skin }}\right) \quad(\text { in } \mathrm{Kcal} / \mathrm{h})
$$

Radiant heat exchange

$$
\begin{aligned}
& (\mathrm{R})=6.6\left(T_{\text {Radiant }}-T_{\text {Skin }}\right) \quad(\text { in } \mathrm{Kcal} / \mathrm{h}) \\
& T_{\text {Radiant }}=T_{g}+\left(1.8 \times V^{0.5}\right) \times\left(T_{G}-T_{\text {air }}\right)
\end{aligned}
$$

Evaporative heat loss

$$
(\mathrm{E})=14 \times V^{0.6} \times\left(P_{\text {Skin }}-P_{\text {air }}\right)
$$


Where: $\mathrm{T}_{\text {skin }}=35^{\circ} \mathrm{C}$, Vapor pressure of skin $\left(\mathrm{P}_{\text {skin }}\right)=42$ $\mathrm{mm}$ of $\mathrm{Hg}$

One another expression for HSI relating the metabolic rate $(\mathrm{M})$ (in Btu/h), dry bulb $\left(\mathrm{T}_{\mathrm{db}}\right)$ and wall surface $\left(\mathrm{T}_{\mathrm{w}}\right)$ temperatures (in ${ }^{\circ} \mathrm{F}$ ), air velocity $\left(\mathrm{V}_{\mathrm{ar}}\right)$ (in $\mathrm{ft} / \mathrm{min}$ ) and vapor pressure $\left(\mathrm{p}_{\mathrm{a}}\right.$ ) (in $\mathrm{mm}$ of $\mathrm{Hg}$, where $42 \mathrm{~mm}$ of $\mathrm{Hg}$ represents the skin vapor pressure at $95^{\circ} \mathrm{F}$ based on relationship with the experimental studies is given as:

$$
\mathrm{HSI}=\frac{M+22\left(T_{w}-95\right)+2{ }^{\star} V_{a r}^{0.5}\left(T_{d b}-95\right)}{10.3^{\star} V_{a r}^{0.4}\left(42-p_{a}\right)}
$$

The HSI limit values ranges between -20 to more than 100 , where -20 (indicates cold strain); 0 (indicates no heat strain); 10 to 30 (indicates mild to moderate thermal strain); 40 to 60 (indicates high strain and need of acclimatization); 70 to 90 (indicates high severe thermal strain and requires proper hydration and consumption of fluids); 100 (indicates maximum thermal strain that can be tolerated by an acclimatized user) and greater than 100 indicates that the work exposure time must be limited based on the rise in core body temperature, which is then given in terms of Allowable exposure time (AET) given by the expression as:

$$
\mathrm{AET}=2440 /[\text { Ereq-Emax }]
$$

Humidex: Humidex or Humidity Index developed by the Canadian meteorological service department [53] is a direct index for evaluating, how hot the thermal environment feels to an average person, when combining the effect of heat and humidity (dew point temperature). The resultant value specifies the corresponding range of discomfort experienced by the person ranging from less than $27{ }^{\circ} \mathrm{C}$ (little/no discomfort) to greater than $54{ }^{\circ} \mathrm{C}$ (heat stroke). Humidex is limited to two environmental factors only i.e. air temperature and humidity, but fails to consider the effect of solar radiation, air velocity, clothing and metabolic rate. Humidex is different from the heat index which uses the dew point temperature rather than relative humidity. The expression for Humidex is given as follows:

$$
\begin{gathered}
\text { Humidex }=\mathrm{T}_{\mathrm{db}}+\left[0.5555\left(\mathrm{P}_{\mathrm{a}}-10\right)\right] \\
\mathrm{P}_{\mathrm{a}}=6.11^{\star} \mathrm{e}^{\left[5417.7530^{*}\left((1 / 273.16)-\left(1 / \mathrm{T}_{\mathrm{dp} \mathrm{in} \mathrm{Kevin}}\right)\right)\right]}
\end{gathered}
$$

Where; $\mathrm{T}_{\mathrm{db}}=$ Dry bulb temperature $\left({ }^{\circ} \mathrm{C}\right), \mathrm{P}_{\mathrm{a}}=$ Vapor pressure $(\mathrm{hPa})$, and $\mathrm{T}_{\mathrm{dp}}=$ Dew point temperature $\left({ }^{\circ} \mathrm{C}\right)$.

The Humidex range values are based on the comfort/ discomfort level experienced by the user in an environment. The range varies as: $<29^{\circ} \mathrm{C}$ (indicates no discomfort experienced), 30 to $34^{\circ} \mathrm{C}$ (indicates slight discomfort experienced), 35 to $39^{\circ} \mathrm{C}$ (indicates evident discomfort experienced), 40 to $45^{\circ} \mathrm{C}$ (indicates intense discomfort experienced), greater than $45^{\circ} \mathrm{C}$ but less than equal to $54^{\circ} \mathrm{C}$ (indicates dangerous discomfort experienced) and $>54^{\circ} \mathrm{C}$ (indicates probable heat stroke).

Heat Index (HI): The heat index (HI) is another popular index used for the assessment of hot environments involving the use of a regression equation based on two environmental factors i.e. relative humidity $(\mathrm{RH})$ and air temperature $\left(\mathrm{T}_{\mathrm{a}}\right)$ [54]. The developed regression equation is based on results produced by the Steadman heat model [55]. The heat index regression equation was developed by Rothfusz and is given by:

$$
\begin{aligned}
& \mathrm{HI}=-42.379+2.04901523^{\star} \mathrm{T}_{\mathrm{a}}+10.14333127^{\star} \\
& \mathrm{RH}-0.22475541^{\star} \mathrm{T}_{\mathrm{a}}{ }^{\star} \mathrm{RH}-0.00683783^{\star} \\
& \mathrm{T}_{\mathrm{a}}{ }^{2}-0.05481717^{\star} \mathrm{RH}^{2}+0.00122874^{\star} \mathrm{T}_{\mathrm{a}}^{2} \\
& \mathrm{RH}+0.00085282^{\star} \mathrm{T}^{\star} \mathrm{RH}^{2}-0.00000199^{\star} \mathrm{T}_{\mathrm{a}}{ }^{2} \mathrm{RH}^{2}
\end{aligned}
$$

Where; $\mathrm{T}_{\mathrm{a}}$ in degree Fahrenheit and $\mathrm{RH}$ in percent

The regression equation considered few adjustments/ correction factors for two different conditions as: If $\mathbf{R H}$ $<13 \%$ and $\mathrm{T}$ varies between $80^{\circ} \mathrm{F}$ to $112^{\circ} \mathrm{F}$; then the following adjustment is subtracted from the regression equation.

$$
\begin{aligned}
\text { Adjustment } 1= & {[(13-R H) / 4]^{\star} } \\
& {\left[\left(17-\left|T_{a}-95\right|\right) / 17\right]^{1 / 2} }
\end{aligned}
$$

On the other hand, if the $\mathbf{R H}>85 \%$ and $\mathbf{T}_{\mathbf{a}}$ varies between $80^{\circ} \mathrm{F}$ to $87^{\circ} \mathrm{F}$; then following adjustment is added to the regression equation:

$$
\text { Adjustment } 2=\left[\frac{R H-85}{10}\right] *\left[\frac{87-T_{a}}{5}\right]
$$

There are few limitations of this regression equation and is considered invalid under extreme $\mathrm{T}_{\mathrm{a}}$ and $\mathrm{RH}$ conditions beyond the data limits specified by Steadman model [54]. $\mathrm{HI}$ is also limited in considering the effects of other environmental factors (wind, solar radiation) and also personal factors (i.e. metabolic rate and clothing factor). HI value computed by the regression equation is limited by an error value of $\pm 1.3^{\circ} \mathrm{F}$. The limit values of $\mathrm{HI}$ indicates various control measures based on reducing the heat stress exposure for four different ranges. HI range varies from 27 to $32^{\circ} \mathrm{C}$ (caution: includes possible fatigue with continuous activity and may results in heat cramps), 32 to $41^{\circ} \mathrm{C}$ (extreme caution: includes possible heat cramps, heat exhaustion and continual work may result in heat stroke), 41 to $54^{\circ} \mathrm{C}$ (indicates danger: more chances of heat cramps, heat exhaustion and possible heat cramps with prolonged work activity) and $>54^{\circ} \mathrm{C}$ (indicates extreme danger: impending/threatening heat stroke). 
Thermal Work Limit (TWL): A rational heat stress index used for the assessment of thermal work environment based on five different environmental parameters (i.e. wind velocity, atmospheric pressure, dry-bulb, wet-bulb and globe temperatures) and further utilizes the clothing factor; estimating the safe limit for utmost continual sustainable metabolic rate $\left(\mathrm{W} / \mathrm{m}^{2}\right)$ for the targeted work ambience; such that the physiological parameters like (CBT) core body temperature $\left(<38.20^{\circ} \mathrm{C}\right)$ and sweat rate $(<1.2 \mathrm{~kg} / \mathrm{hr})$ remain within a safe limit. The resultant value of the TWL index is a single number specifying maximum metabolic rate (W/ $\left.\mathrm{m}^{2}\right)$ in terms of the metabolic heat generated per unit meter of body surface area [56]. The higher value of TWL suggests that the thermal conditions doesn't impose any restrictions on work. For moderate TWL values, properly hydrated selfpaced workers will be able to overcome the thermal stress by adjusting their work rate. And corresponding to low TWL values, heat storage (increase in CBT) will affect the user and TWL provides guidelines for work cycle management to predict the safe work rest-cycling schedules. TWL range varies from $60 \mathrm{~W} / \mathrm{m}^{2}$ (resting) to $380 \mathrm{~W} / \mathrm{m}^{2}$. When the dew point temperature of the surrounding air is greater than the skin/clothing temperature; then TWL results are not considered valid [56]. Few studies revealed that, TWL may perform better than the WBGT, for predicting the impact of environmental heat stress in outdoor and indoor work environments [57]. Authors analysed that there was a difference between TWL and WBGT values; as WBGT values computed for the same locations imposed severe and unnecessary limitations on the work cycle, there by resulting in productivity losses. Based on the study, it was found that TWL provides a more workable strategy for managing heat stress and is more realistic and organized than WBGT [57]. The recommended limits for the TWL index are divided into four limit zones i.e. withdrawal, (TWL $<115$ $\left.\mathrm{W} / \mathrm{m}^{2}\right)$, Buffer $\left(115 \mathrm{~W} / \mathrm{m}^{2}<\mathrm{TWL}<140 \mathrm{~W} / \mathrm{m}^{2}\right)$, acclimatization $\left(140 \mathrm{~W} / \mathrm{m}^{2}<\mathrm{TWL}<220 \mathrm{~W} / \mathrm{m}^{2}\right)$, unrestricted (TWL $>220 \mathrm{~W} / \mathrm{m}^{2}$ ) and each limit zone suggest various control interventions based on reducing the heat stress exposure among users.

Predicted four hour sweat rate (P4SR): P4SR index is considered as an effective heat stress assessment tool in evaluating high temperature work conditions, but not considered suitable for temperatures below $28^{\circ} \mathrm{C}$ [58]. It considers the combined effect of environmental variables (air temperature, humidity, air velocity, and radiant temperature) and personal factors (metabolic rate and clothing insulation) to predict the thermal stress endured by the worker based on evaluating the sweat rate, heart rate or core body temperature. It's expressed in terms of a nomogram. The P4SR evaluation requires the calculation of basic four hour sweat rate (B4SR) based on the measured parameters i.e. radiant temperature or dry bulb temperature and wet bulb temperature using the nomogram. The P4SR equation then can be expressed as:

$$
\begin{aligned}
P 4 S R= & B 4 S R+0.37{ }^{\star} I_{c l o}+ \\
& \left(0.012+0.001^{\star} I_{c l o}\right)(M-63)
\end{aligned}
$$

Further modifications/corrections are considered while computing the P4SR index, if (Ta) is not equal to ( $\mathrm{Tg}$ ) then an addition of $0.4(\mathrm{Tg}-\mathrm{Ta}){ }^{\circ} \mathrm{C}$ is done to wet bulb temperature, if metabolic rate $>63 \mathrm{~W} / \mathrm{m}^{2}$, then an addition to wet bulb temperature based on the graph. For clothed men, the wet bulb temperature is increased by $\left(1.5^{\star} \mathrm{I}_{\mathrm{clo}}\right)^{\circ} \mathrm{C}$.

Tropical Summer Index: TSI is an empirical index developed by CBRI, Roorkee based on the Indian climatic conditions. It gives an equivalent temperature of still air at constant $\mathrm{RH}$ of $50 \%$, which provides the similar thermal sensation experienced by a user as the actual environment under consideration $[59,60]$. It is expressed by a mathematical relation as:

$$
\begin{aligned}
\mathrm{TSI}= & \left(0.308^{\star} \mathrm{T}_{\mathrm{wb}}\right)+\left(0.745^{\star} \mathrm{T}_{\mathrm{g}}\right) \\
& -\left(2.06^{\star} \sqrt{\mathrm{V}_{\mathrm{ar}}+0.841}\right)
\end{aligned}
$$

A simplified equation for rapid evaluation has also been given as:

$$
\mathrm{TSI}=\frac{1}{3} * \mathrm{~T}_{\mathrm{wb}}+\frac{3}{4} * \mathrm{~T}_{\mathrm{g}}-2 \sqrt{\mathrm{V}_{\mathrm{ar}}}
$$

Where; $\mathrm{T}_{\mathrm{wb}}$ is wet-bulb temperature $\left({ }^{\circ} \mathrm{C}\right), \mathrm{T}_{\mathrm{g}}$ : globe temperature $\left({ }^{\circ} \mathrm{C}\right), \mathrm{V}_{\mathrm{ar}}$ : air velocity $(\mathrm{m} / \mathrm{s})$. TSI thermal sensation range values varies as follows: TSI $<19^{\circ} \mathrm{C}$ (too cool), 19-25 ${ }^{\circ} \mathrm{C}$ (slightly cool), $25-30^{\circ} \mathrm{C}$ (comfortable), $30-34^{\circ} \mathrm{C}$ (slightly warm), and $>34^{\circ} \mathrm{C}$ (very hot).

However, apart from leading heat stress indices (providing quantitative assessment) in force; subjective assessment tools (qualitative heat stress analysis) like High Occupational Temperature: Health and Productivity Suppression (HOTHAPS) questionnaire, Heat strain score index (HSSI) have also been widely used for assessing the subjective thermal perception of the employed users $[6,61]$.

\section{Physiological Parameters as Heat Strain Indicators}

Merely an assessment of heat stress indices is not enough for evaluating the thermal stress exposure at a workplace. There is a further need for validating these indices in order to come to an appropriate conclusion. Heat strain is the response given by the human body in reaction to heat stress; in terms of changes in physiological parameters like heart rate, core body temperature, sweating, and skin temperature variations. The heat exchange mechanism of human body is governed by three physiological mechanisms: (i) Vasomotor (concerned with the skin blood flow, which increases or decreases the skin temperature based on CBT to support heat transfer between body and the surroundings), (ii) Sweating (excessive heat transfer between the core and skin 
is required to maintain proper CBT, which is achieved by sweating), and (iii) Shivering (disorganized muscular activity to increase heat production rate for controlling the core temperature in cold work conditions) [28, 39]. However, there are several valid physiological parameters that reflects the heat strain experienced by the user under hot and humid work conditions, yet three valid physiological parameters i.e. skin temperature, heart rate (HR) and core body temperature (CBT); are most widely used [43].

Skin Temperature: It represents the temperature over the surface of the body and varies significantly over the body surface under different ambient conditions (especially in cold environments). Although it's a physiological parameter of importance, but it is not considered as a valid indicator of thermal strain experienced by the user. But, it can be utilized as a good indicator for assessing thermal comfort or in combination with other physiological parameters to give better estimation of thermal strain [39]. It can be distinguished in two ways, one is the local skin temperature $\left(\mathrm{T}_{\mathrm{Lsk}}\right)$ directly measured at any point of body surface, other is the mean skin temperature $\left(\mathrm{T}_{\mathrm{Msk}}\right)$ involving the weighted summation of several local skin temperatures over the entire body surface. It is widely affected by several heat transfer mechanism like convection, radiation, conduction and evaporative heat transfer at skin surface. The variations in the blood temperature and skin blood flow from the core to the skin also affects the body skin temperature. For hot work conditions, the threshold limit value for $\mathrm{T}_{\text {Lsk }}$ is $43{ }^{\circ} \mathrm{C}$ [43]. Several weighing schemes (depends on the number of measurement points, ranging from 1 to 14) have been proposed, to evaluate the $\mathrm{T}_{\mathrm{Msk}}$ based on the local skin temperatures measured at different body surfaces $[39,43]$. Generally, three weighing schemes have been proposed by ISO 9886 standard i.e. 4-point method, 8-point method and 14-point method. Each method considers a weighing coefficient assigned with the $\mathrm{T}_{\text {Lsk }}$. The $\mathrm{T}_{\text {Msk }}$ based on the three weighing schemes have been expressed as:

$$
\begin{gathered}
T_{\text {Msk -4 point method }}=0.28^{\star} T_{\text {neck }}+0.28^{\star} T_{\text {right scapula }} \\
+0.16^{\star} T_{\text {left hand }}+0.28^{\star} T_{\text {right shin }} \\
T_{\text {Msk -8 point method }}=0.07^{\star} T_{\text {forehead }}+0.175^{\star} T_{\text {right scapula }} \\
+0.05^{\star} T_{\text {left hand }}+0.175^{\star} T_{\text {left upper chest }}+0.20^{\star} T_{\text {left calf }} \\
+0.07^{\star} T_{\text {right arm in upper location }}+0.07^{\star} T_{\text {left arm in lower location }} \\
+0.19^{\star} T_{\text {right anterior thigh }} \\
T_{M \text { sk-16 point method }}=0.07142857^{\star}\left[T_{\text {forehead }}+T_{\text {right scapula }}\right. \\
+T_{\text {left hand }}+T_{\text {left upper chest }}+T_{\text {left calf }}+T_{\text {right arm in upper location }} \\
+T_{\text {left arm in lower location }}+T_{\text {right anterior thigh }}+T_{\text {neck }} \\
+T_{\text {right abdomen }}+T_{\text {left paravertebral }}+T_{\text {left posterior thigh }} \\
\left.+T_{\text {right instep }}+T_{\text {right shin }}\right]
\end{gathered}
$$

In hot work conditions, less skin temperature variation occurs as compared to the cold environments. Higher the variations in temperature, higher will be the number of measurement points required to provide a valid estimation [39]. So, fewer measurement points are required to evaluate $\mathrm{T}_{\text {Msk }}$ in hot conditions, as lesser skin temperature gradients are present on the body surface as compared to the cold working conditions. One appropriate estimation being widely used for hot working conditions was provided by Ramanathan [62], which evaluates $\mathrm{T}_{\mathrm{Msk}}$ by using four different measurement locations as:

$$
\begin{aligned}
& T_{\text {Msk } \text {-Ramanathan(4-point method })}=0.3^{\star} T_{\text {left upper chest }} \\
& \quad+0.3^{\star} T_{\text {left front shoulder }}+0.2^{\star} T_{\text {right interior thigh }}+0.3^{\star} T_{\text {right shin }}
\end{aligned}
$$

Core Body Temperature (CBT): It is one of the most influential physiological parameter that represents the thermal strain experienced by the user in response to the hot working conditions. The core represents the cell tissues located at a sufficient depth inside body that are not affected by the temperature gradients through skin surface tissue, thus proving to be more effective in representing the physiological response w.r.t change in thermal conditions. With an increase of 0.2 to $0.3^{\circ} \mathrm{C}$ from normal CBT $\left(37^{\circ} \mathrm{C}\right)$, the skin blood flow increases and sweating begins. The risk of exhaustion increases within $38-39^{\circ} \mathrm{C}$, whereas failure of the thermoregulatory system may occur above 39 ${ }^{\circ} \mathrm{C}$ and above $42^{\circ} \mathrm{C}$, even death could occur. There are few indicators of CBT that represents the deep body temperature using different measurement techniques [43]. These includes oesophageal temperature $\left(T_{\mathrm{es}}\right)$, rectal temperature $\left(T_{\mathrm{re}}\right)$, intra-abdominal temperature $\left(T_{\mathrm{ab}}\right)$, oral temperature $\left(T_{\mathrm{or}}\right)$, tympanic temperature $\left(T_{\mathrm{ty}}\right)$, auditory canal temperature $\left(T_{\text {ac }}\right)$, and urine temperature $\left(T_{\mathrm{ur}}\right)$. Each of these indicators have few advantages and limitations (as described in Table 4) based on various factors like ease/complexity of measurement, measurement procedure, accuracy, work conditions, interference with work, annoyance to subjects, cost of instrumentation, and health issues [43]. For slow rate heat accumulation, the CBT (temperature rise by $1^{\circ} \mathrm{C}$ in more than $1 \mathrm{hr}$.) limit value is $38^{\circ} \mathrm{C}$. For acclimatized workers, (who have been repeatedly exposed to the specific work environment) a higher limit value for $\mathrm{CBT}>38.5^{\circ} \mathrm{C}$ can be tolerated, however under no means the rise in CBT greater than $39^{\circ} \mathrm{C}$ is acceptable $[39,43]$.

Heart Rate (HR): It is another physiological parameter of importance (measured in beats per minute, bpm) and is strongly correlated with the CBT [43]. It provides an effective estimation of the thermal strain experienced by the worker in high-heat work environment. The particular term of importance while considering this physiological parameter is the thermal component of heart rate $\left(\Delta H R_{T}\right)$, which increases with the rise in CBT. For per $1^{\circ} \mathrm{C}$ rise in CBT, the corresponding increase in $\mathrm{HR}$ is known as thermal cardiac 
Table 4. Various indicators for Core body temperature (CBT)

\begin{tabular}{|c|c|c|c|c|}
\hline CBT Indicators & Advantages & Limitations & $\begin{array}{l}\text { Body location/ } \\
\text { Sensor }\end{array}$ & Condition limits \\
\hline $\begin{array}{l}\text { Oesophageal } \\
\text { temperature }\left(T_{e s}\right)\end{array}$ & $\begin{array}{l}\text { It shows the temperature } \\
\text { variations accurately } \\
\text { than other indicators } \\
\text { (peak values), continuous } \\
\text { measurement }\end{array}$ & $\begin{array}{l}\text { Measurement complexity, } \\
\text { cause slight work interference, } \\
\text { high annoyance to user }\end{array}$ & $\begin{array}{l}\text { Oesophagus lower part, } \\
\text { Temperature transducer }\end{array}$ & $\begin{array}{l}\text { Catheter length should } \\
\text { be around } 25 \% \text { of } \\
\text { subject height, with } \\
\text { diameter } \leq 1.5 \mathrm{~mm}\end{array}$ \\
\hline $\begin{array}{l}\text { Oral temperature } \\
\left(T_{\text {or }}\right)\end{array}$ & Low cost, ease of use & $\begin{array}{l}\text { Variations due to external } \\
\text { conditions }\end{array}$ & $\begin{array}{l}\text { Underneath tongue, } \\
\text { Temperature transducer }\end{array}$ & $\begin{array}{l}\mathrm{T}_{\mathrm{a}}>30^{\circ} \mathrm{C} \text { (warm } \\
\text { conditions), Must be } \\
\text { kept for minimum } 5 \\
\text { min. time period }\end{array}$ \\
\hline $\begin{array}{l}\text { Rectal } \\
\text { temperature }\left(T_{\mathrm{re}}\right)\end{array}$ & $\begin{array}{l}\text { Independent of ambient } \\
\text { conditions, provides } \\
\text { mean value of CBT, } \\
\text { continuous measurement }\end{array}$ & $\begin{array}{l}\text { Moderate annoyance to } \\
\text { subjects }\end{array}$ & $\begin{array}{l}\text { Rectum, Temperature } \\
\text { transducer }\end{array}$ & $\begin{array}{l}\text { Probe must be inserted } \\
\text { at least distance of } 100 \\
\text { mm past the anus edge }\end{array}$ \\
\hline $\begin{array}{l}\text { Tympanic/ } \\
\text { Eardrum } \\
\text { temperature }\left(T_{\text {ty }}\right)\end{array}$ & $\begin{array}{l}\text { Limited work } \\
\text { interference, slight } \\
\text { annoyance to users, cost } \\
\text { effective, low instrument } \\
\text { complexity }\end{array}$ & $\begin{array}{l}\text { Doesn't provide continuous } \\
\text { measurement }\end{array}$ & $\begin{array}{l}\text { Tympanic } \\
\text { membrane, Infrared } \\
\text { (IR) temperature } \\
\text { measurement, thermal } \\
\text { transducer }\end{array}$ & $\begin{array}{l}\mathrm{T}_{\mathrm{a}}: 18^{\circ} \mathrm{C} \text { to } 58^{\circ} \mathrm{C} \\
\mathrm{V}_{\mathrm{ar}}:<1 \mathrm{~m} / \mathrm{s} \\
\mathrm{T}_{\mathrm{mrt}} \text { must be close to } \mathrm{T}_{\mathrm{a}}\end{array}$ \\
\hline $\begin{array}{l}\text { Urine } \\
\text { temperature }\left(T_{\text {ur }}\right)\end{array}$ & $\begin{array}{l}\text { Slight work interference, } \\
\text { no health hazard } \\
\text { involved, low cost }\end{array}$ & $\begin{array}{l}\text { Measurement depend on the } \\
\text { quantity of urine present, } \\
\text { provides discontinuous } \\
\text { readings, psychological } \\
\text { annoyance }\end{array}$ & $\begin{array}{l}\text { Urine from the bladder, } \\
\text { temperature transducer } \\
\text { inserted in collecting box }\end{array}$ & $\begin{array}{l}\mathrm{T}_{\mathrm{a}}: 15^{\circ} \mathrm{C} \text { to } 25^{\circ} \mathrm{C} \\
\text { Transducers must } \\
\text { have very small time } \\
\text { constant }\end{array}$ \\
\hline $\begin{array}{l}\text { Intra-abdominal } \\
\text { temperature }\left(T_{\mathrm{ab}}\right)\end{array}$ & $\begin{array}{l}\text { Temperature range varies } \\
\text { between }\left(T_{\mathrm{es}}\right) \text { and }\left(T_{\mathrm{re}}\right), \\
\text { Independent of ambient } \\
\text { conditions (except strong } \\
\text { radiant heat impinging } \\
\text { on the abdomen), } \\
\text { provides effective } \\
\text { continuous measurement }\end{array}$ & $\begin{array}{l}\text { Measuring complexity, high } \\
\text { equipment cost, moderate } \\
\text { annoyance to user, may cause } \\
\text { health hazards }\end{array}$ & $\begin{array}{l}\text { Transition from } \\
\text { intestinal tract to } \\
\text { stomach and intestine } \\
\text { Swallowable capsule type } \\
\text { temperature transducer }\end{array}$ & $\begin{array}{l}\text { Radio pill must be } \\
\text { calibrated in water bath } \\
\left(37^{\circ} \mathrm{C}\right) \text { before being } \\
\text { swallowed }\end{array}$ \\
\hline $\begin{array}{l}\text { Auditory canal } \\
\text { temperature }\left(T_{\mathrm{ac}}\right)\end{array}$ & $\begin{array}{l}\text { provides continuous } \\
\text { measurement, cost } \\
\text { effective }\end{array}$ & $\begin{array}{l}\text { Considered as an indicator } \\
\text { of the combined effect of the } \\
\text { core and skin temperatures, } \\
\text { (than core temperature } \\
\text { indicator only), annoyance to } \\
\text { subjects }\end{array}$ & $\begin{array}{l}\text { Auditory meatus walls } \\
\text { near tympanum }\end{array}$ & $\begin{array}{l}\text { Maximum difference } \\
\text { between the } \mathrm{T}_{\mathrm{a}} \text { and } T_{\mathrm{ac}} \\
\text { is } 10^{\circ} \mathrm{C}\end{array}$ \\
\hline
\end{tabular}

reactivity (in beats $/ \mathrm{min} .{ }^{\circ} \mathrm{C}$ ), with average increase of 33 bpm in HR. Under extreme conditions, HR must be used in conjunction with CBT for better estimation of the thermal strain [39]. The maximum value of $\left(\Delta \mathrm{HR}_{T}\right)$ for $\mathrm{CBT}$ of $39^{\circ} \mathrm{C}$ is limited to $60 \mathrm{bpm}$. The $\mathrm{HR}$ limit value at workplace can be evaluated by the relation: $\mathrm{HR}_{\mathrm{L}}=\left(185-0.65^{\star}\right.$ age $)$; whereas the maximum $\mathrm{HR}$ that can be sustained is given as: $\mathrm{HR}_{\mathrm{L}-\text { Sustained }}=(180-$ age $)$. The heart rate thermal component can be expressed as under:

$$
\Delta H R_{T}=H R_{r}-H R_{o}
$$

Body-mass loss (Sweating): For hot work conditions, another important parameter of concern is the body-mass loss due to sweating. It considers the evaporative heat loss from skin due to sweating, sweat droplets falling from the skin surface and the sweat that accumulates in the clothing worn. For acclimatized workers, the sweat loss limit is 1.25 litres per hour and is limited to 1 litres per hour for unacclimatized workers [43]. The body-mass loss is given as the difference between the measured body mass at the beginning of the work and at the end of the work cycle. It evaluates the net water balance requirements for the user in 
relation with the risk of dehydration, which indicates the thermal strain level experienced by the user.

Several other parameters such as urine specific gravity (USG) relating the dehydration level experienced by the user (differentiating exposure level w.r.t changes in urine color); immunological parameters (indicating suppressions at sub-cellular levels with reduction in leukocytes levels and blood cell counts, higher induction of Micronuclei (MN) frequency in lymphocytes) could also be utilized as an effective indicators of occupational heat strain under highheat furnace work-environments. However, related concerns like psychological annoyance to user, measurement complexity, and required medical expertise make these parameters a bit complicated to implement; yet they could be quite effective.

\section{DISCUSSION}

The thermal ambience of furnace workforce is influenced by the combination of several factors (six dominant factors that affects the human thermal response i.e. four environmental and two personal factors) like clothing, climatic conditions, and physical activity performed $[63,64]$ As compared to developed countries, several research studies have been conducted under various industrial sectors, but there is still a lot of research work required to be executed in developing countries; as the climatic/geographical conditions and target population differs from one country to another. So, there is need and scope to explore various environmental factors affecting thermal ambience in a rigorous manner. A research conducted in South-east Asia revealed that workers employed under several work sectors were exposed to extreme level of thermal stress, resulting in production loss and serious health issues among users [7]. In India, during hot summer season, millions of underprivileged workers are strained by harsh thermal workconditions with subsequent health challenges, reduced productivity and daily incomes [6]. One such research study related to manufacturing sector in India, found that there was significant reduction in workers' productivity due to rise in ambient temperatures at the workplace [8]. The hot and humid conditions leads to excessive perspiration and makes the working conditions tougher and unfavourable for human working [65]. Table 5 summarizes the research work of several authors related to thermal stress evaluation for workers employed under various high-heat work-sectors.

From assessment studies (depicted in Table 5), it was observed that occupational heat impacts have received limited attention in developing countries despite workers being a vulnerable sub-population to climate change and very few appropriate studies have been reported on heat stress under high heat furnace work environments. In developing countries, there's lack of research considering the combined effect of climatic conditions and occupational heat exposures on worker's health and productivity. Mostly, previous studies are based on the assessment-orientedapproach rather than action-oriented-approach. There is need for adaptation research with purposive action focused on improving the workplace thermal conditions rather than just providing assessment and suggestions.

\section{Decline in Work-Productivity and Financial burden}

Workers employed under industrial work-sectors are often exposed to excess levels of heat stress with resultant reduction in work-capacity and serious occupational health consequences due to climatic change and several other parameters under high-heat work conditions. In developing countries, less information is available on the combined effect of climatic and industrial heat exposure. This occupational heat exposure has a negative impact on the workers well-being; which declines their work efficiency and in turns affect the production of the plant. Kjellstrom et al. [1] stated that climate change results in reduced work capacity in heat-exposed work environment and found this as a major issue for developing countries in achieving economic and social development. It was analysed that work capacity rapidly reduces, as WBGT exceeds from $26^{\circ} \mathrm{C}$ to $30^{\circ} \mathrm{C}$. However, developed countries having less economic constraints could implement specific adaptation measures in terms of occupational heat exposures using expensive methods/techniques as compared to low-income (developing) countries. Mohamed and Srinavin [70] proposed a productivity model with respect to dominant thermal environment parameters; relating work-productivity with PMV thermal comfort index for three different work categories (i.e. Light, moderate, and heavy construction work tasks). Authors presented three robust regression models (as described in equation) covering major variability of the productivity with respect to thermal work-conditions.

$$
\begin{gathered}
P_{L}=102-0.80^{\star} P M V-1.84^{\star} P M V^{2} \\
P_{M}=102+1.19^{\star} P M V-2.17^{\star} P M V^{2} \\
P_{H}=83+21.64{ }^{\star} P M V-9.53^{\star} P M V^{2}+0.91^{\star} P M V^{3}
\end{gathered}
$$

Kjellstrom et al. [71] reported that rise in occupational heat exposure due to climate change may lead to labor productivity losses with subsequent economic declines. Authors proposed a productivity versus heat stress based graph model for acclimatized workers; relating work capacity (in \%; maximum hour duration that user should be engaged working) as function of WBGT value for different work-intensity levels $(200 \mathrm{~W}, 300 \mathrm{~W}, 400 \mathrm{~W}, 500$ $\mathrm{W}$; ranging from light to very-high workloads). Ismail et al. [72] evaluated the combined effect of temperature and relative humidity on worker productivity in an automotive 
Table 5. Related assessment studies for high-heat work environments in developing countries

\begin{tabular}{|c|c|c|c|c|}
\hline Author/ Year & $\begin{array}{l}\text { Sample } \\
\text { Size/ } \\
\text { Climatic } \\
\text { location }\end{array}$ & $\begin{array}{l}\text { Indices/ } \\
\text { Parameters used }\end{array}$ & Methodology & Key Findings \\
\hline $\begin{array}{l}\text { Srivastava et al. } \\
2000[15]\end{array}$ & $\begin{array}{l}\text { Not } \\
\text { specified } \\
\text { Gujarat, } \\
\text { India } \\
\text { Hot } \\
\text { semi-arid } \\
\text { climate }\end{array}$ & $\begin{array}{l}\text { WBGT, CET, MRT } \\
\text { (CET: Corrected } \\
\text { Effective } \\
\text { Temperature; MRT: } \\
\text { Mean Radiant } \\
\text { Temperature) }\end{array}$ & $\begin{array}{l}\text { Evaluating heat stress } \\
\text { exposure levels using selected } \\
\text { indices to assess the thermal } \\
\text { health hazards present at a } \\
\text { glass manufacturing plant }\end{array}$ & $\begin{array}{l}\text { The heat stress indices values exceeded } \\
\text { much more than the permissible limit } \\
\text { values (average WBGT }=40^{\circ} \mathrm{C} \text { ); author } \\
\text { suggested revising the existing standards } \\
\text { based on the local climatic conditions. }\end{array}$ \\
\hline $\begin{array}{l}\text { Pourmahabadian } \\
\text { et al. } 2008 \text { [14] }\end{array}$ & $\begin{array}{l}\text { Not } \\
\text { specified } \\
\text { Iran } \\
\text { Cold } \\
\text { Semi-Arid } \\
\text { climate }\end{array}$ & WBGT, CET, HSI & $\begin{array}{l}\text { Assessing occupational heat } \\
\text { exposure level under two } \\
\text { different sections in a glass } \\
\text { industry using environmental } \\
\text { variables and different heat } \\
\text { stress indices (i.e. WBGT, } \\
\text { CET, and HSI) }\end{array}$ & $\begin{array}{l}\text { The relationship between all the } \\
\text { evaluated environmental parameters } \\
\text { (expect air velocity) with respect to } \\
\text { different body heights (head, abdomen } \\
\text { and ankle) was found to be insignificant. } \\
\text { However, positive correlation was } \\
\text { observed between the WBGT, HSI, and } \\
\text { CET. }\end{array}$ \\
\hline $\begin{array}{l}\text { Pinto et al. } 2012 \\
\text { [66] }\end{array}$ & $\begin{array}{l}55 \text { workers } \\
\text { Brazil } \\
\text { Temperate } \\
\text { oceanic } \\
\text { climate }\end{array}$ & $\begin{array}{l}\text { PMV, PPD } \\
\text { (PMV: Predicted } \\
\text { Mean Vote; PPD: } \\
\text { Predicted percentage } \\
\text { of dissatisfied) }\end{array}$ & $\begin{array}{l}\text { To identify the association } \\
\text { between the PMV and } \\
\text { thermal sensation (S) among } \\
\text { workers employed in metal } \\
\text { industry and developing a } \\
\text { linear multiple regression } \\
\text { equation. }\end{array}$ & $\begin{array}{l}\text { It was observed that the mean radiant } \\
\text { temperature, air-temperature, and } \\
\text { metabolic rate could positively influence } \\
\text { the employees thermal comfort } \\
\text { sensations. }\end{array}$ \\
\hline $\begin{array}{l}\text { Venugopal et al. } \\
2016 \text { [7] }\end{array}$ & $\begin{array}{l}442 \\
\text { workers } \\
\text { Southern } \\
\text { India } \\
\text { Tropical } \\
\text { savanna } \\
\text { climate }\end{array}$ & WBGT & $\begin{array}{l}\text { The study aims to evaluate } \\
\text { occupational thermal stress } \\
\text { and subsequent impacts } \\
\text { on workers' health and } \\
\text { productiveness; by collecting } \\
\text { qualitative and quantitative } \\
\text { data from } 18 \text { different } \\
\text { workplaces, under both } \\
\text { organized and unorganized } \\
\text { work-sectors. }\end{array}$ & $\begin{array}{l}\text { No significant difference was observed } \\
\text { among the respective organized and } \\
\text { unorganized work-sectors. During } \\
\text { summer and winter time-periods, } \\
\text { around } 82 \% \text { and } 42 \% \text { workers were } \\
\text { affected by higher WBGT values than the } \\
\text { recommended limits. } \\
\text { Workers involved in intensive physical } \\
\text { work activities reported more heat- } \\
\text { related health morbidities and reduced } \\
\text { productivity. Significant association was } \\
\text { observed among the workers subjective } \\
\text { thermal perception on health and } \\
\text { productivity impacts under the existing } \\
\text { thermal work-conditions. }\end{array}$ \\
\hline $\begin{array}{l}\text { Giahia et al. } 2016 \\
\text { [18] }\end{array}$ & $\begin{array}{l}20 \text { Male } \\
\text { Smelters } \\
\text { Iran } \\
\text { Hot- } \\
\text { summer } \\
\text { Mediterran } \\
\text { Climate }\end{array}$ & $\begin{array}{l}\text { WBGT, MRT; } \\
\text { Core body } \\
\text { temperature (CBT): } \\
\text { aural temperature }\end{array}$ & $\begin{array}{l}\text { Proposing design } \\
\text { interventions based on } \\
\text { decreasing the radiant heat } \\
\text { exposure generating from } \\
\text { a blast furnace followed by } \\
\text { analysing the effectiveness } \\
\text { of proposed design controls } \\
\text { using WBGT, MRT indices } \\
\text { and CBT. }\end{array}$ & $\begin{array}{l}\text { Using design control interventions, the } \\
\text { MRT and WBGT values decreased by } \\
26.5^{\circ} \mathrm{C} \text { and } 5.2^{\circ} \mathrm{C} \text { respectively; While the } \\
\text { workers' CBT reduced by } 2.6^{\circ} \mathrm{C} \text {. }\end{array}$ \\
\hline
\end{tabular}




\begin{tabular}{|c|c|c|c|c|}
\hline Author/ Year & $\begin{array}{l}\text { Sample } \\
\text { Size/ } \\
\text { Climatic } \\
\text { location }\end{array}$ & $\begin{array}{l}\text { Indices/ } \\
\text { Parameters used }\end{array}$ & Methodology & Key Findings \\
\hline $\begin{array}{l}\text { Hajizadeh et al. } \\
2016 \text { [27] }\end{array}$ & $\begin{array}{l}184 \text { brick } \\
\text { kilns } \\
\text { workers, } \\
\text { Qom, Iran } \\
\text { Desert } \\
\text { Climate }\end{array}$ & $\begin{array}{l}\text { WBGT, HSI, PHS, } \\
\text { CET, ET, DI; } \\
\text { Skin temperature, } \\
\text { blood pressure, heart } \\
\text { rate, ear-carotid } \\
\text { artery temperature, } \\
\text { oral temperature. } \\
\text { (ET: Effective } \\
\text { Temperature) }\end{array}$ & $\begin{array}{l}\text { The objective is to find an } \\
\text { optimal heat stress index for } \\
\text { brick kilns workers engaged } \\
\text { in different work activities, } \\
\text { by comparing the results of } \\
\text { different thermal indices }\end{array}$ & $\begin{array}{l}\text { Workers engaged in indoor kiln were } \\
\text { exposed to higher environmental } \\
\text { parameters values as compared to } \\
\text { outdoor; except for air-velocity. } \\
\text { Statistically significant associations were } \\
\text { observed between WBGT and carotid } \\
\text { artery temperature, skin temperature, } \\
\text { and oral temperature. } \\
\text { WBGT and DI were found to be highly } \\
\text { correlated with each other. WBGT was } \\
\text { suggested as the optimal index for Brick } \\
\text { kilns work environment. }\end{array}$ \\
\hline $\begin{array}{l}\text { Krishnamurthy et } \\
\text { al. } 2017 \text { [6] }\end{array}$ & $\begin{array}{l}84 \text { workers } \\
\text { India } \\
\text { Tropical } \\
\text { savanna } \\
\text { climate }\end{array}$ & WBGT & $\begin{array}{l}\text { Analysing health and } \\
\text { productivity loss among } \\
\text { workers employed in high } \\
\text { heat work conditions, due to } \\
\text { various thermal stress factors. }\end{array}$ & $\begin{array}{l}90 \% \text { of WBGT values exceed the TLV } \\
\text { limits. Maximum value of WBGT } \\
\left(41.7^{\circ} \mathrm{C}\right) \text { was found in the coke oven area } \\
\text { and minimum }\left(27.2^{\circ} \mathrm{C}\right) \text { in the control } \\
\text { room zone. } \\
\text { Around } 10.6 \% \text { workers reported } \\
\text { productivity loss (in terms of not } \\
\text { achieving specified targets) due to high } \\
\text { thermal stress. }\end{array}$ \\
\hline $\begin{array}{l}\text { Sugiono et al. } 2017 \\
\text { [67] }\end{array}$ & $\begin{array}{l}22 \text { workers } \\
\text { Indonesia } \\
\text { Tropical } \\
\text { Savanna } \\
\text { Climate }\end{array}$ & PMV, PPD & $\begin{array}{l}\text { Computational fluid } \\
\text { dynamics (CFD) simulation } \\
\text { has been used to evaluate } \\
\text { the existing human thermal } \\
\text { comfort level among } \\
\text { workers employed in plastics } \\
\text { manufacturing company } \\
\text { based on PMV-PPD } \\
\text { calculations; followed by } \\
\text { suggesting CAD simulation } \\
\text { based design modifications } \\
\text { focussed on increasing the } \\
\text { thermal comfort level among } \\
\text { workers. }\end{array}$ & $\begin{array}{l}\text { Replacing existing ceiling glass material; } \\
\text { from clear glass to reflective clear glass ( } 6 \\
\text { mm thickness; with } 23 \% \text { transmittance). } \\
\text { The design modifications resulted in } \\
\text { decrease of PMV by } 0.64 \text { point (existing } \\
\text { PMV: } 1.83 \text { to } 2.82 \text {; modified PMV: } 1.63 \\
\text { to } 2.18 \text { ). } \\
\text { With PPD resulted } 13.8 \% \text { increase } \\
\text { in thermal comfort (existing PPD: } \\
68.9 \% \text { TO } 98 \% \text {, modified PPD: } 58.2 \% \\
\text { TO } 84.2 \% \text { and ambient temperature } \\
\text { decrease by } 4^{\circ} \mathrm{C} \text {. }\end{array}$ \\
\hline $\begin{array}{l}\text { Fahed et al. } 2018 \\
\text { [29] }\end{array}$ & $\begin{array}{l}100 \\
\text { Workers, } \\
\text { Turkey } \\
\text { Humid } \\
\text { subtropical } \\
\text { climate }\end{array}$ & $\begin{array}{l}\text { WBGT, PSI, HSI; } \\
\text { Physiological } \\
\text { parameters (Heart } \\
\text { Rate, CBT: Ear canal } \\
\text { temperature) }\end{array}$ & $\begin{array}{l}\text { Examined the impacts of } \\
\text { occupational heat stress on } \\
\text { the health and productivity } \\
\text { of steel plant workers during } \\
\text { the summer season. }\end{array}$ & $\begin{array}{l}\text { Average WBGT, PSI and HSI values were } \\
\text { found to be } 30.89 \pm 1.1{ }^{\circ} \mathrm{C}, 3.15 \pm 0.64 \\
\text { and } 118.5 \pm 18.61 \% \text {. } \\
\text { It was observed that work activities close } \\
\text { to furnaces and hot rolling area were } \\
\text { exposed to high levels of heat stress. } \\
\text { For heavy workload, PMV-productivity } \\
\text { model indicated a productivity loss } \\
\text { ranging from } 20 \text { to } 30 \% \text { respectively. } \\
\text { Higher correlation was observed for } \\
\text { HSI with the heart rate. However, a } \\
\text { significant relationship was found for } \\
\text { WBGT and PSI indices with the core } \\
\text { body temperature. }\end{array}$ \\
\hline
\end{tabular}




\begin{tabular}{|c|c|c|c|c|}
\hline Author/ Year & $\begin{array}{l}\text { Sample } \\
\text { Size/ } \\
\text { Climatic } \\
\text { location }\end{array}$ & $\begin{array}{l}\text { Indices/ } \\
\text { Parameters used }\end{array}$ & Methodology & Key Findings \\
\hline $\begin{array}{l}\text { Rabeiy } \\
2019 \text { [37] }\end{array}$ & $\begin{array}{l}100 \text { Bakery } \\
\text { workers } \\
\text { Egypt } \\
\text { Hot dessert } \\
\text { climate }\end{array}$ & $\begin{array}{l}\text { WBGT, PSI, } \\
\text { Physiological } \\
\text { parameters (heart } \\
\text { rate, CBT: oral } \\
\text { temperature) }\end{array}$ & $\begin{array}{l}\text { Heat stress evaluations } \\
\text { among bakery workers using } \\
\text { WBGT and PSI indices; } \\
\text { comparison with national } \\
\text { and international limits } \\
\text { followed by suggesting } \\
\text { control measures. }\end{array}$ & $\begin{array}{l}\text { WBGT index values were found to } \\
\text { be higher than the TLVs specified by } \\
\text { American Conference of Government } \\
\text { Industrial Hygienists (ACGIH) and } \\
\text { Egyptian Environmental Law (EEL); } \\
\text { for acclimated workers performing } \\
\text { moderate work activities. } \\
\text { Around } 42 \% \text { workers were exposed to } \\
\text { high heat stress values; with PSI ranging } \\
\text { from low to moderate level. }\end{array}$ \\
\hline $\begin{array}{l}\text { Bolghanabadia et } \\
\text { al. } 2019 \text { [61] }\end{array}$ & $\begin{array}{l}103 \\
\text { Bakery } \\
\text { workers } \\
\text { Iran, } \\
\text { Tropical } \\
\text { and } \\
\text { Subtropical } \\
\text { Steppe } \\
\text { Climate }\end{array}$ & $\begin{array}{l}\text { WBGT, Heat strain } \\
\text { score index (HSSI); } \\
\text { oral and drumhead } \\
\text { temperature, heart } \\
\text { rate, BMI }\end{array}$ & $\begin{array}{l}\text { Investigating the heat strain } \\
\text { rate among three different } \\
\text { group of bakery workers } \\
\text { (i.e. bakers, bread grabber, } \\
\text { and pastry makers) under } \\
\text { existing physical conditions } \\
\text { followed by analysing } \\
\text { relationship between } \\
\text { physiological variables }\end{array}$ & $\begin{array}{l}\text { WBGT exceeded the TLVs for } 80 \% \\
\text { workers with WBGT Mean (SD) value } \\
\text { of } 28.69(1.41) \text {. Oral and drum-head } \\
\text { temperatures were highest among } \\
\text { workers engaged in baking activity, } \\
\text { as compared to other two groups. } \\
\text { Significant relationship was observed } \\
\text { between WBGT and HSSI (p-value } \\
<0.001, \mathrm{r}=0.61 \text { ); and with other } \\
\text { considered physiological variables, } \\
\text { except BMI. }\end{array}$ \\
\hline $\begin{array}{l}\text { Mohammadian et } \\
\text { al. } 2019 \text { [16] }\end{array}$ & $\begin{array}{l}90 \text { rolling } \\
\text { mill } \\
\text { workers } \\
\text { Tehran, } \\
\text { Iran } \\
\text { Cold } \\
\text { semi-arid } \\
\text { climates }\end{array}$ & $\begin{array}{l}\text { WBGT, DI; } \\
\text { CBT: tympanic } \\
\text { temperature, HR }\end{array}$ & $\begin{array}{l}\text { Evaluating the thermal } \\
\text { stress exposure among } \\
\text { workers employed in a } \\
\text { rolling mill; using WBGT } \\
\text { and DI followed by analysing } \\
\text { their relationship with the } \\
\text { physiological parameters i.e. } \\
\text { CBT and HR. }\end{array}$ & $\begin{array}{l}\text { Significant differences were observed } \\
\text { for physiological parameters (i.e. CBT, } \\
\text { HR) in between resting and working } \\
\text { conditions. } \\
\text { The mean scores for DI and WBGT were } \\
\text { reported as: DI Mean (SD): } 28.28^{\circ} \mathrm{C} \\
(1.11) \text {; WBGT Mean (SD): } 29.05^{\circ} \mathrm{C} \\
(1.27) \text {. } \\
\text { Highest correlation was observed } \\
\text { between WBGT and heart rate followed } \\
\text { by CBT. }\end{array}$ \\
\hline $\begin{array}{l}\text { Zarea et al. } 2019 \\
\text { [38] }\end{array}$ & $\begin{array}{l}50 \text { Mine } \\
\text { workers } \\
\text { Iran } \\
\text { Hot desert } \\
\text { climate }\end{array}$ & $\begin{array}{l}\text { UTCI, TSI, WBGT, } \\
\text { WBDT (Wet bulb } \\
\text { dry temperature); } \\
\text { Physiological } \\
\text { parameters (blood } \\
\text { pressure, HR, } \\
\text { CBT: tympanic } \\
\text { temperature, and } \\
\text { skin temperature) } \\
\text { (UTCI: Universal } \\
\text { Thermal Climate } \\
\text { Index) }\end{array}$ & $\begin{array}{l}\text { Determining environmental } \\
\text { and workers' physiological } \\
\text { responses followed by } \\
\text { evaluating the respective } \\
\text { indices (i.e. UTCI, WBGT, } \\
\text { WBDT, and TSI) and } \\
\text { examining the correlation } \\
\text { among the physiological } \\
\text { responses and respective } \\
\text { thermal stress indices. }\end{array}$ & $\begin{array}{l}\text { The average values (with SD) for UTCI, } \\
\text { WBGT, WBDT, and TSI indices were } \\
34.59^{\circ} \mathrm{C}(1.51), 24.59^{\circ} \mathrm{C}(0.62), 28.37^{\circ} \mathrm{C} \\
(0.82) \text {, and } 31.51^{\circ} \mathrm{C}(0.7) \text {. } \\
\text { Strongest association was observed } \\
\text { between UTCI and WBDT indices } \\
\text { followed by WBGT and WBDT. } \\
\text { No significant correlation was observed } \\
\text { among the evaluated indices and workers } \\
\text { physiological responses (p-value }> \\
0.05) \text {, except only significant association } \\
\text { observed for WBGT and TSI indices } \\
\text { with the skin temperature. }\end{array}$ \\
\hline
\end{tabular}




\begin{tabular}{|c|c|c|c|c|}
\hline Author/ Year & $\begin{array}{l}\text { Sample } \\
\text { Size/ } \\
\text { Climatic } \\
\text { location }\end{array}$ & $\begin{array}{l}\text { Indices/ } \\
\text { Parameters used }\end{array}$ & Methodology & Key Findings \\
\hline $\begin{array}{l}\text { Venugopal et al. } \\
2019 \text { [68] }\end{array}$ & $\begin{array}{l}120 \text { Steel } \\
\text { Workers } \\
\text { South } \\
\text { India } \\
\text { Tropical } \\
\text { savanna } \\
\text { climate }\end{array}$ & $\begin{array}{l}\text { WBGT; } \\
\text { CBT: tympanic } \\
\text { temperature, Sweat } \\
\text { rate, Urine specific } \\
\text { gravity (USG), } \\
\text { Micronuclei (MN) } \\
\text { frequency in } \\
\text { lymphocytes }\end{array}$ & $\begin{array}{l}\text { Examining the relationship } \\
\text { among occupational thermal } \\
\text { stress and DNA damage } \\
\text { among steel plant workers } \\
\text { prone to high-heat work } \\
\text { environment. }\end{array}$ & $\begin{array}{l}\text { Higher risk of DNA damage was } \\
\text { observed among the exposed workers } \\
\text { as compared to the control group }\left(\mathrm{X}^{2}=\right. \\
47.1 ; \mathrm{p}<0.0001) \text {. Significant increase } \\
\text { was observed in the micro nuclei (MN) } \\
\text { frequency for the affected group as } \\
\text { compared to control group (Adj. OR = } \\
23.3,95 \% \text { CI 8.0-70.8); } \\
\text { Among exposed group higher risk } \\
\text { of DNA damage was associated with } \\
\text { workers engaged in high-heat work } \\
\text { activities (Adj. OR }=81.4 ; \text {; } 95 \% \text { CI } \\
21.3-310.1 \text { ); also having significant } \\
\text { relationship with years of exposure (Adj. } \\
\text { OR = 29.7; } 95 \% \text { CI } 2.8-315.5 \text { ), leading to } \\
\text { higher induction of MN-frequency. }\end{array}$ \\
\hline $\begin{array}{l}\text { Jafari et al. } 2020 \\
\text { [30] }\end{array}$ & $\begin{array}{l}55 \text { foundry } \\
\text { workers, } \\
\text { Iran } \\
\text { Cold } \\
\text { Semi-Arid } \\
\text { climate }\end{array}$ & $\begin{array}{l}\text { WBGT; } \\
\text { Blood cell count, } \\
\text { Enzyme-linked } \\
\text { immunosorbent } \\
\text { assay (ELISA) }\end{array}$ & $\begin{array}{l}\text { To analyse the effect of } \\
\text { occupational heat stress } \\
\text { on the immunological } \\
\text { parameters of foundry } \\
\text { workers in Iran with } \\
\text { reference to increase in } \\
\text { WBGT values. }\end{array}$ & $\begin{array}{l}\text { Under high heat conditions, there was } \\
\text { decrease in the leukocytes levels and } \\
\text { white blood cell counts among foundry } \\
\text { workers which indicates possible decline } \\
\text { in the workers' immune system. }\end{array}$ \\
\hline $\begin{array}{l}\text { Venugopal et al. } \\
2020 \text { [69] }\end{array}$ & $\begin{array}{l}340 \text { steel } \\
\text { workers, } \\
\text { South } \\
\text { India } \\
\text { Tropical } \\
\text { savanna } \\
\text { climate }\end{array}$ & $\begin{array}{l}\text { WBGT; } \\
\text { CBT: tympanic } \\
\text { temperature, Urine } \\
\text { Specific Gravity } \\
\text { (USG), } \\
\text { Renal/urologic } \\
\text { anomalies }\end{array}$ & $\begin{array}{l}\text { Analysing the risk of renal/ } \\
\text { urologic anomalies (i.e. } \\
\text { kidney stones and other } \\
\text { structural renal anomalies) } \\
\text { among steel workers exposed } \\
\text { to high-heat work conditions. }\end{array}$ & $\begin{array}{l}\text { For } 220 \text { workers, heat exposure values } \\
\text { exceeded the TLVs; with WBGT } \\
33.2^{\circ} \mathrm{C}\left( \pm 3.8^{\circ} \mathrm{C}\right) \text {. Significant relationship } \\
\text { was observed between the workers' heat } \\
\text { exposure level, rise in CBT and urine } \\
\text { specific gravity (relating to dehydration } \\
\text { level). } \\
91 \text { workers were tested for renal } \\
\text { anomalies using portable renal } \\
\text { ultrasound scanner. Around } 33 \% \text { were } \\
\text { tested positive for having renal anomalies } \\
\text { (i.e. kidney/ureteral stones and urethral } \\
\text { calculi). } \\
\text { These anomalies were found higher } \\
\text { among heat-exposed workers (WBGT }> \\
30^{\circ} \mathrm{C} \text { ) as compared to unexposed group } \\
\text { and was also affected by the year of } \\
\text { exposure ( } \geq 5 \text { years). }\end{array}$ \\
\hline
\end{tabular}

industrial workstation and proposed a mathematical equation, which could predict the workers' production rate based on the RH and WBGT temperature. Stated thermalproductivity models could be implemented in hot furnace work environments; to analyse the occupational heat exposure impacts on user's work-capabilities.

In China, 9550 work-related injury claims and insurance compensation pay-outs (for the period of January,
2011 to December, 2012) were analysed from the work related injury insurance system, indicating an insurance pay-out of 282.3 million Chinese Yuan [73]. Further, the relation between WBGT index and work-related injury claims \& insurance compensation pay-outs were calculated. It was found that injury claims increased with rising WBGT values. Around, $4.8 \%$ of work-related injuries and $4.1 \%$ insurance pay-outs were attributed to heat exposure 
for WBGT above threshold limit values (TLVs). Another research study examined the relationship among climatic conditions, worker's productivity and health status under two different work conditions [74] i.e. indoor industrial work-environment (pottery industry, power plant, knife industry) and outdoor work-conditions (agricultural and construction). Qualitative analysis revealed worker's perceived productivity loss ranging from $10 \%$ to $60 \%$ among construction and industrial workers. Beheshti et al. [75] evaluated exposure of thermal stress and its subsequent performance-loss among workers; functioning under highheat indoor work conditions. It was concluded that extreme workplace heat could significantly decrease the labour work performance and consequently, their production capacity. The performance loss attributable to occupational heat stress was determined by using performance loss versus thermal stress graph proposed by Kjellstrom et al. [71]. Venugopal et al. [7] studied occupational heat stress and its impact on the health and productivity of workers by collecting qualitative and quantitative data from 18 different workplaces in both organized and unorganized work sectors. Workers with heavy workloads reported more heatrelated health issues and reduced productivity. Another researcher analyzed the unsteady work environments in the working face of hot coal mines; with results revealing rise in skin and core temperatures with increasing levels of relative humidity. Air temperature around $22^{\circ} \mathrm{C}$ to $24^{\circ} \mathrm{C}$ was found to be a control factor to improve the thermal tolerance. The unsteady thermal condition significantly affect the mine worker's thermal sensations and physiological responses which in turns effects the productivity [76]. Kjellstrom and Growe [77] reported impact of climate change on rising heat stress exposure levels imposing severe health suppressions among work-force in near future and suggested utmost need for remedial solutions based on protecting workers health and productivity. Lee et al. [78] examined the negative impacts of climate change related heat stress on labor work-productivity in South Korea and concluded futuristic decline in labor productivity during middle of $21^{\text {st }}$ century (2041-2070) and consequent outdoor work productivity decline of $26.1 \%$ from current scenario by the end of $21^{\text {st }}$ century. Pogacar et al. [79] analysed the climate change projections based on mean air temperature, maximum air temperature (in terms of number of days) and selected thermal indices over past decades; indicating a positive trend in terms of heat stress during the summer season. Case study conducted among 400 manufacturing workers revealed stressful work conditions (with 96\% workers reporting uncomfortable work environment) directly impacting their health and work-productivity. According to the International Labour Organisation (ILO) 2019 report, by 2030 heat stress will be accountable to loss of approximately 80 million Jobs around the world in which India will be worst hit expecting to loss of around 34 million full-time jobs, which will lead to large scale economic and productivity losses [80].

\section{Negative Health Impacts on Workers}

In developing countries, the relationship between occupational high-heat exposure and its possible health impacts has not been clearly well established. Studies related to this occupational hazard are limited because of several challenges and constraints in developing countries. Prevalent limitations necessitates the urgency for appropriate

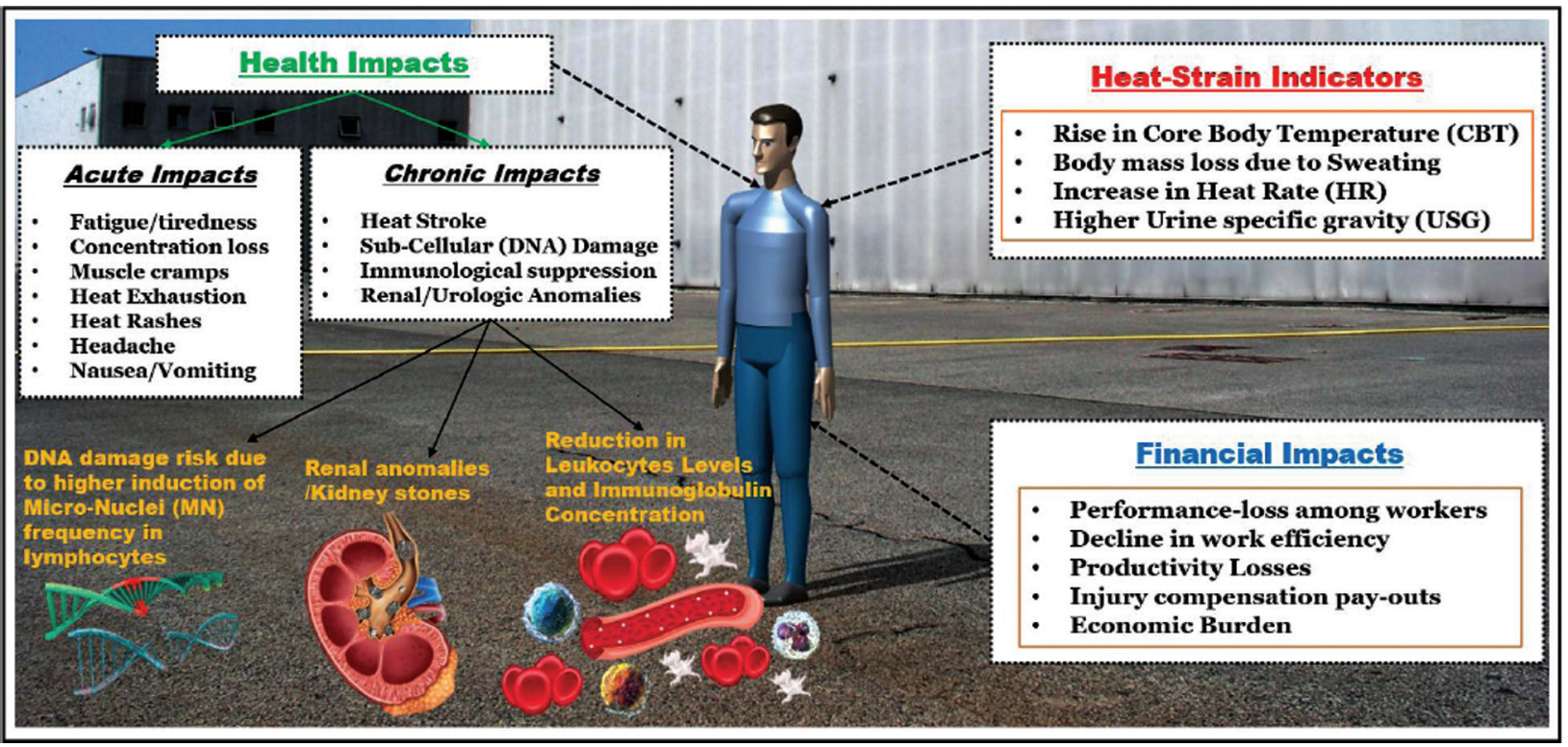

Figure 4. Possible negative impacts on workers' health and safety. 
assessment studies; for analysing the existing conditions more effectively and provide valid conclusions based on improving the worker's social wellbeing. During summer season, lot of indigent labourers are influenced by extreme high-heat work ambience, which results in severe health risks followed by reduced productivity and economic burden [1, 5-8]. Krishnamurthy et al. [6] evaluated the negative impacts of heat stress on the health and productivity of workers working under high heat industries in southern India and determined the dehydration status of the worker by interpreting urine color with a urine color chart. Around $90 \%$ of WBGT index values exceeded the TLV limits and $70 \%$ of workers reported change in urine color and volume indicating dehydration/lack of periodic fluid consumption. Varghese et al. [81] suggested a positive association among the hot climatic conditions and heat related occupational injuries, with possible negative impacts involving fatigue, psychomotor performance loss, reduced concentration, and lack of alertness. Xiaodong et al. [82] identified that the period from 14:00 to $15: 00 \mathrm{PM}$ as the most hazardous for workers throughout the day and impose high heat stress on the human body. Also, Nunfamioi et al. [83] observed that inadequate prevention and control policies, adversely affect workers' health and safety as well as their productive capacity and social well-being. Venugopal et al. [68] reported that apart from occupational heat-related morbidities, the issues of damages at sub-cellular level (DNA damage) is prevalent among workers exposed to high working temperatures. Higher risk of DNA damage was observed among the exposed workers as compared to the control group; with significant increase observed for the micro nuclei (MN) frequency in lymphocytes of 120 steel plant workers (exposed group) as compared to unexposed workers (control group). Among exposed group, higher risk was associated with workers engaged in high-heat work activities (also having significant relationship with years of exposure); leading to higher induction of MN-frequency. Jafari et al. [30] analysed the effect of occupational heat stress on the immunological parameters of foundry workers in Iran. For higher WBGT index values, there was prominent decrease in the white blood cell counts and lymphocyte levels among the exposed group with relative increase in neutrophils levels and the neutrophil - lymphocyte ratio, which negatively affects and weakens the workers' immune system. Figure 4 summarizes the possible negative impacts of occupational heat stress on workers' well-being.

\section{Role of Control Interventions in Ameliorating Heat Stress}

The role of design control interventions could be considered beneficial in improving the thermal ambience of a work environment, which may include engineering control interventions like improving ventilation design, installing reflective thermal barriers, sensor based intelligence and even simulation based control studies. These design control interventions may be taken as an effective and important control measure in reducing the exposure levels upto the desired permissible limits [84-88]. One study utilized engineering control interventions (air-cooler design) to improve the workplace condition among operators working in evaporator assembly area of an electronics company. Study aimed at improving the work productivity based on reducing the percentage of dissatisfaction (PPD) among operators [9]. HSI \& WBGT measurements were considered at 11 work locations, where PPD value were measured before and after to validate the design intervention using CBE thermal comfort tool. The results indicated significant decrease in the heat stress measurements. Sugiono et al. [67] utilized computational fluid dynamics (CFD) simulation (in ANSYS Fluent) to evaluate the existing thermal comfort level among workers employed in a plastics manufacturing plant and suggested CAD based design modification (by replacing existing ceiling glass material with reflective clear glass; having $6 \mathrm{~mm}$ thickness and 23\% transmittance). Proposed modification indicated thermal comfort improvements among workers based on predicted mean vote (PMV) and predicted percentage of dissatisfied (PPD) evaluations (where ambient temperature decreased by $4^{\circ} \mathrm{C}, \mathrm{PMV}$ decreased by 0.64 point and PPD showed $13.8 \%$ increase in thermal comfort). Giahia et al. [18] study aims to design and implement radiant heat controls, using a heat absorbing system (i.e. cooling tower with water circulation) in the furnace body and installing steel framed structure (with multi-layered reflective aluminum covering) in the workstation followed by analyzing the efficiency of the employed interventions using valid and standardized indices of radiant heat. Heat stress indices and core body temperature were measured before and after to validate the design interventions. Engineering control interventions were proved to be effective in reducing radiant heat by decreasing the mean radiant temperature (MRT) and WBGT values by $26.5^{\circ} \mathrm{C}$ and $5.2^{\circ} \mathrm{C}$ respectively, whereas workers' core body temperature decreased by $2.6^{\circ} \mathrm{C}$. Mohammadyan et al. [89] implemented a designed cool spot with double layer insulation in order to reduce the WBGT and MRT levels among workers in a foundry industry. The implemented design intervention resulted in reducing the WBGT value (from $29.6^{\circ} \mathrm{C}$ to $22.8^{\circ} \mathrm{C}$ ) and MRT value (from $43.8^{\circ} \mathrm{C}$ to $28.6^{\circ} \mathrm{C}$ ), thereby limiting the heat stress exposure level among workers. So in crux these engineering based interventions could lower the heat-stress exposure levels upto desired permissible limits under the existing thermal work-conditions; however simulation studies may be helpful in suggesting appropriate design interventions based on improving thermal work ambience. Although, recent technological advancements in sensor intelligence could enable heat stress data monitoring and analysis at substantially lower cost; with potential benefits like early warning systems, real-time physiological monitoring (indicating heat strain) and automation control based on threshold limit values. With several associated 
Table 6. Studies describing role of control interventions in ameliorating heat stress

\begin{tabular}{|c|c|c|c|}
\hline Authors & $\begin{array}{l}\text { Work } \\
\text { Environment }\end{array}$ & Methodology & $\begin{array}{l}\text { Proposed Design/ Control } \\
\text { Intervention }\end{array}$ \\
\hline \multicolumn{4}{|c|}{ "CFD Simulation Approach" } \\
\hline Kamar et al. [90] & $\begin{array}{l}\text { Non-air } \\
\text { conditioned } \\
\text { Mosque } \\
\text { building; } \\
\text { Malaysia }\end{array}$ & $\begin{array}{l}\text { In present study, authors used } \\
\text { CFD based design strategy for } \\
\text { improving the thermal comfort } \\
\text { inside a large spaced mosque } \\
\text { building. Field measurement } \\
\text { followed by 3D-CAD model of } \\
\text { Mosque building was analysed } \\
\text { using CFD approach for different } \\
\text { suggested design models. }\end{array}$ & $\begin{array}{l}\text { Author proposed four } \\
\text { suitable design modifications: } \\
\text { Installing Exhaust fans (with } \\
\text { 1-m diameter) on Mosque } \\
\text { building walls. Four cases of } \\
\text { suitable combination were } \\
\text { considered: } \\
\text { Case } 1 \text { - Roof-12 fans, } \\
\text { Case } 2 \text { - west-side wall-12 fans, } \\
\text { Case } 3 \text { - east-side wall-12 fans, } \\
\text { Case } 4 \text { - south-side wall-10 fans }\end{array}$ \\
\hline $\begin{array}{l}\text { Alam and Salve } \\
\text { [91] }\end{array}$ & $\begin{array}{l}\text { Non-air } \\
\text { conditioned } \\
\text { Railway Pantry } \\
\text { Car; India }\end{array}$ & $\begin{array}{l}\text { Present study aimed at } \\
\text { enhancing the thermal work } \\
\text { conditions inside the Railway } \\
\text { Pantry Car Kitchen. Onsite } \\
\text { field measurements followed by } \\
\text { analysing proposed 3D-CAD } \\
\text { based design modifications using } \\
\text { CFD approach in ANSYS Fluent. }\end{array}$ & $\begin{array}{l}\text { Author proposed four design } \\
\text { modifications for pantry } \\
\text { kitchen: } \\
\text { Case 1-4 Exhaust fans (front } \\
\text { wall), } 2 \text { Carriage fans (roof) } \\
\text { Case 2-4 Exhaust fans (front } \\
\text { wall), } 2 \text { Carriage fans (left and } \\
\text { right side wall) } \\
\text { Case 3-4 Exhaust fans (front } \\
\text { wall), } 4 \text { air vents (lower front } \\
\text { wall) } \\
\text { Case 4-4 Exhaust fans (front } \\
\text { wall), } 3 \text { Carriage fans (bottom } \\
\text { surface) }\end{array}$ \\
\hline
\end{tabular}

\section{"Engineering Control Interventions"}

Mohammadyan Foundry To reduce heat stress exposure et al. [89] Industry; Iran levels among workers employed in a foundry industry.
Designed cool spot for workers
Key Findings

Installing ten exhaust fans (1-m diameter) at the south-side wall, at a floor height of 6 metres (m) has a potential of reducing the PMV index by $75-95 \%$ and the PPD index by $87-91 \%$.

CFD results revealed that case-I design model provided a better design concept by improving air ventilation and decreasing the indoor ambient temperature during all cooking periods; as compared to the existing and other case models.

Implemented design intervention resulted in reduction of the WBGT from $29.6^{\circ} \mathrm{C}$ to $22.8^{\circ} \mathrm{C}$, and MRT decreased from $43.8^{\circ} \mathrm{C}$ to $28.6^{\circ} \mathrm{C}$; thereby reducing the heat stress exposure among workers. Experimental results revealed reduction in radiant temperature from $44.04^{\circ} \mathrm{C}$ to $35.8^{\circ} \mathrm{C}$ and decrease in WBGT value from $28.88^{\circ} \mathrm{C}$ to $26.57^{\circ} \mathrm{C}$

Using both interventions, the MRT and WBGT value decreased by $26.5^{\circ} \mathrm{C}$ and $5.2^{\circ} \mathrm{C}$; while the workers $\mathrm{CBT}$ reduced by $2.6^{\circ} \mathrm{C}$.
Giahia et. al. Steel Plant; To reduce radiant heat exposure [18] Iran 20 Male Smelters generating from a blast furnace interventions followed by analysing the efficacy of the control interventions using heat stress indices and workers' core body temperature (CBT).
Author proposed installing double layered reflective priant heat exposures among Implemented a heat absorbing system (cooling tower with water circulation) in the furnace body and installing steel framed structure (with multi-layered reflective Aluminium covering) in the workstation. 


\begin{tabular}{|c|c|c|c|c|}
\hline Authors & $\begin{array}{l}\text { Work } \\
\text { Environment }\end{array}$ & Methodology & $\begin{array}{l}\text { Proposed Design/ Control } \\
\text { Intervention }\end{array}$ & Key Findings \\
\hline Huda [9] & $\begin{array}{l}\text { Electronic } \\
\text { manufacturing } \\
\text { plant; } \\
\text { Indonesia } \\
11 \text { industrial } \\
\text { workers }\end{array}$ & $\begin{array}{l}\text { To analyse and improve the effect } \\
\text { of environmental conditions } \\
\text { on workers thermal comfort } \\
\text { by reducing the predicted } \\
\text { percentage of dissatisfied (PPD) } \\
\text { among employed users. }\end{array}$ & $\begin{array}{l}\text { Proposed ventilation design } \\
\text { using direct evaporative air } \\
\text { cooler as an engineering } \\
\text { control to improve the work } \\
\text { place condition }\end{array}$ & $\begin{array}{l}\text { After implementing the } \\
\text { proposed engineering } \\
\text { control intervention, } \\
\text { PPD value predicted by } \\
\text { CBE thermal comfort } \\
\text { tool reduced to } 34 \% \\
\text { and also HSI reduced to } \\
13.6 \text { (from existing HSI } \\
\text { value of 52); indicating } \\
\text { improvement in workers } \\
\text { thermal comfort. }\end{array}$ \\
\hline Zare et al. [93] & $\begin{array}{l}\text { Laboratory } \\
\text { Environment; } \\
\text { Iran } \\
15 \text { male } \\
\text { University } \\
\text { Students }\end{array}$ & $\begin{array}{l}\text { Present work investigates the } \\
\text { effectiveness of an optimized ice } \\
\text { cooling vest and standardized } \\
\text { paraffin cooling vest on heat } \\
\text { strain parameters under a } \\
\text { controlled environment. }\end{array}$ & $\begin{array}{l}\text { Author proposed low cost } \\
\text { optimized ice cooling vest; } \\
\text { hydrogel filled to increase } \\
\text { ice-pack flexibility; polyvinyl } \\
\text { chloride packs with ethylene } \\
\text { vinyl acetate foam layer to } \\
\text { prevent tissue damage. }\end{array}$ & $\begin{array}{l}\text { Heat strain parameters } \\
\text { varied significantly } \\
\text { during the experimental } \\
\text { study between with and } \\
\text { without wearing cooling } \\
\text { vests. Authors observed } \\
\text { that proposed cooling } \\
\text { vest was as effective as } \\
\text { commercial vest, yet also } \\
\text { cost-effective. }\end{array}$ \\
\hline \multicolumn{5}{|c|}{ "Sensor Based Intelligence" } \\
\hline $\begin{array}{l}\text { Aryal et al. } 2019 \\
{[94]}\end{array}$ & $\begin{array}{l}\text { Laboratory } \\
\text { controlled } \\
\text { environment; } \\
\text { USA } \\
20 \text { participants } \\
\text { (12 male, } \\
8 \text { female) }\end{array}$ & $\begin{array}{l}\text { Utilising wrist-worn sensor } \\
\text { based approach for predicting } \\
\text { user's thermal comfort /sensation } \\
\text { and satisfaction. }\end{array}$ & $\begin{array}{l}\text { Skin-temperature, ambient } \\
\text { temperature, galvanic skin } \\
\text { response (GSR), was measured } \\
\text { using infrared temperature } \\
\text { sensor, environmental sensor, } \\
\text { GSR sensor, and FLIR thermal } \\
\text { imaging camera. }\end{array}$ & $\begin{array}{l}\text { Results revealed that } \\
\text { environmental sensor } \\
\text { data in conjunction } \\
\text { with physiological } \\
\text { sensor data resulted } \\
\text { in thermal sensation } \\
\text { prediction improvement } \\
\text { of } 3 \%-5 \% \text {; as compared } \\
\text { to environmental sensors } \\
\text { data only. }\end{array}$ \\
\hline $\begin{array}{l}\text { Jha and } \\
\text { Tukkaraja } 2020 \\
\text { [95] }\end{array}$ & $\begin{array}{l}\text { Laboratory } \\
\text { scale model for } \\
\text { underground } \\
\text { mining sites; } \\
\text { USA }\end{array}$ & $\begin{array}{l}\text { Conceptualization for real-time } \\
\text { monitoring and assessment } \\
\text { of underground climatic } \\
\text { conditions using sensors and } \\
\text { GIS (Geographic information } \\
\text { system) based approach. }\end{array}$ & $\begin{array}{l}\text { Ambient temperature, Relative } \\
\text { humidity, Carbon monoxide } \\
\text { was monitored using DHT11 } \\
\text { temperature-humidity sensor } \\
\text { and carbon monoxide sensor. }\end{array}$ & $\begin{array}{l}\text { Proposed design } \\
\text { described a risk-based } \\
\text { warning system which } \\
\text { could provide a safer } \\
\text { and comfortable work- } \\
\text { environment for users' } \\
\text { working underground. }\end{array}$ \\
\hline
\end{tabular}

benefits, these control interventions in combination with standardized heat stress indices could play a dominant role in improving the health and safety of users' employed under hot stressful work environments. Table 6 summarizes few research studies demonstrating the role of control interventions in ameliorating heat stress.

\section{Gaps in the Present Approach and Future Directions}

Present literature review focused on analysing occupational heat stress under high-heat furnace work environments with special reference to industrially developing countries. Present work also reviews the concerned heat stress parameters associated with high heat work zones. However, few gaps have been observed in the present approach. Apart from the associated heat stress parameters like environmental, personal, and physiological factors, subsequent impacts of heat stress on the workers' cognitive/mental work ability have not been discussed in this study. Although, present work reviewed the possible negative impacts such as heat related health suppressions, safety issues and reduced work productivity associated with high heat work sectors, yet there is need for additional study describing more site-specific sustainable solutions/ pathways to reduce the negative impacts of occupational 
heat stress under high heat environments; with emphasis on improving the thermal work conditions and enhancing worker productivity. So, a futuristic literature review could also be performed keeping these shortcomings in mind.

\section{CONCLUSION}

From the present literature review, it may be concluded that heat stress is an ignored occupational health hazard significantly affecting the workers' well-being; particularly under high-heat furnace work-sectors in developing countries. The combination of several factors (like air temperature, radiant heat, air velocity, and relative humidity) surrounding the furnace workplace (as well as the metabolic heat and worn clothing) negatively impacts the workers' health; which declines their work efficiency and in turns affect the production capacity.

ISO standards (ISO7243, ISO9886, and ISO7933) could provide more in-depth analysis of heat stress parameters under hot and humid work environments, when used in conjunction with the supporting standards (ISO9920 and ISO8996). Several indices have been developed for the assessment of heat stress exposure, but each varies depending on the considered environmental, personal, and physiological factors. Also, these indices may differ based on their suitability with respect to the particular work-conditions and different geographical locations. Previous studies reveals that WBGT index may be used as an optimal heat stress index, due to its applicability and ease of use in hot work environments. But, merely relying on a single index could generate inappropriate results. So, it must be used as an initial screening method followed by evaluating the physiological parameters (several valid indicators of thermal strain like heart rate, core body temperature, and skin temperature) based on the recommended standard guidelines and also in combination with other widely used heat stress indices like DI, PSI, HSI, TSI, TWL; which would provide better estimation of the thermal strain experienced by the worker.

In developing countries, very few studies have been reported considering the combined effect of climatic conditions and industrial heat exposure on the thermal strain experienced by the worker. Several negative impacts include decreased productivity, reduced daily incomes, and consequent health risks. This chronic heat stress significantly affects the immunological parameters also; resulting in damages at the sub-cellular level (DNA damage), decrease in white blood cell counts and lymphocyte levels; which negatively impacts and weakens the workers' immune system. Apart from this, several other health issues like dehydration, exhaustion, heat stroke, and risk of renal/ urologic anomalies (i.e. kidney stones, urethral calculi, and other structural renal anomalies) are attributable to this occupational heat stress. However, several studies reported that these heat-related morbidities could be reduced by increased awareness for associated risks involved and the consequent financial benefits (with averting injury, poor health outcomes and lost productivity).

Adequate prevention and control policies are necessary to ameliorate the productive capacity and social well-being of the exposed workers. Remedial control measures like sensor based intelligence, proper ventilation design, installing thermal reflective barriers, providing cooling spots, cooling vest-design, and other radiant control measures may prove to be effective in controlling the workplace heat stress exposure. This review study may be beneficial for industrialists, occupational health practitioners, and policy makers (particularly in developing countries) in overviewing the negative impacts of prolonged heat exposure, necessary remedial measures and suitable assessment strategies for monitoring this occupational health hazard under the prevalent high heat work-conditions.

\section{AUTHORSHIP CONTRIBUTIONS}

Authors equally contributed to this work.

\section{DATA AVAILABILITY STATEMENT}

The authors confirm that the data that supports the findings of this study are available within the article. Raw data that support the finding of this study are available from the corresponding author, upon reasonable request.

\section{CONFLICT OF INTEREST}

The author declared no potential conflicts of interest with respect to the research, authorship, and/or publication of this article.

\section{ETHICS}

There are no ethical issues with the publication of this manuscript.

\section{REFERENCES}

[1] Kjellstrom T, Holmer I, Lemke B. Workplace heat stress, health and productivity-an increasing challenge for low and middle-income countries during climate change. Glob Health Action 2009;2:2047. [CrossRef]

[2] Srinivasan K, Maruthy KN, Venugopal V, Ramaswamy P. Research in occupational heat stress in India: Challenges and opportunities. Indian J Occup Environ Med 2016;20:73. [CrossRef]

[3] Chauhan A, Anand T, Kishore J, Danielsen TE, Ingle GK. Occupational hazard exposure and general health profile of welders in rural Delhi. Indian J Occup Environ Med 2014;18:21. [CrossRef] 
[4] Jendritzky G, Tinz B. The thermal environment of the human being on the global scale. Glob Health Action 2009;2:2005. [CrossRef]

[5] Kjellstrom T. Climate change, direct heat exposure, health and well-being in low and middle-income countries. Global health action 2009;2. [CrossRef]

[6] Krishnamurthy M, Ramalingam P, Perumal K, Kamalakannan LP, Chinnadurai J, Shanmugam R, et al. Occupational heat stress impacts on health and productivity in a steel industry in southern India. Saf Health Work 2017;8:99-104. [CrossRef]

[7] Venugopal V, Chinnadurai JS, Lucas RA, Kjellstrom T. Occupational heat stress profiles in selected workplaces in India. Int J Environ Res Public Health 2016;13:89. [CrossRef]

[8] Somanathan E, Somanathan R, Sudarshan A, Tewari $\mathrm{M}$. The impact of temperature on productivity and labor supply: Evidence from Indian manufacturing. Indian Statistical Institute: New Delhi, India; 2015.

[9] Huda LN. The thermal environment effect on the comfort of electronic factory worker. In IOP Conference Series: Earth Environ Sci 2018;126:111. [CrossRef]

[10] Alam MS, Muthiah A, Salve UR. Thermal comfort of the kitchen in pantry cars on Indian railways. Instrum Mes Métrol 2019;18:465-477. [CrossRef]

[11] Alam MS, Muthiah A, Salve UR. Appraisal of thermal comfort in non-air-conditioned and air-conditioned railway pantry car kitchens. Int J Integr Eng 2020;12:318-327. [CrossRef]

[12] The six basic factors. HSE. Available from: https:// www.hse.gov.uk/temperature/thermal/factors.html [Accessed on 15 March, 2020]

[13] Leon LR, Bouchama A. Heat stroke. Compr Physiol 2011;5:611-647. [CrossRef]

[14] Pourmahabadian M, Adelkhah M, Azam K. Heat exposure assessment in the working environment of a glass manufacturing unit. J Environ Health Sci Eng 2008;5:141-147.

[15] Srivastava A, Kumar R, Joseph E, Kumar A. Heat exposure study in the workplace in a glass manufacturing unit in India. Ann Occup Hyg 2000;44:449453. [CrossRef]

[16] Mohammadian F, Sahl Abadi AS, Giahi O, Khoubi J, Zarei AA, Boghsani GT, et al. Evaluation of occupational exposure to heat stress and physiological responses of workers in the rolling industry. Open Public Health J 2019;12:114-120. [CrossRef]

[17] Reheating Furnaces and their Types. Available from: https://www.ispatguru.com/reheating-furnaces-insteel-plants/ [Accessed on 21 March, 2020]

[18] Giahi O, Darvishi E, Aliabadi M, Khoubi J. The efficacy of radiant heat controls on workers' heat stress around the blast furnace of a steel industry. Work 2016;53:293-298. [CrossRef]
[19] Blast Furnace. The Chemistry of Steelmaking. schoolscience.co.uk, 2002. Available from: http:// resources.schoolscience.co.uk/Corus/14-16/steel/ msch2pg2.html.

[20] Assad ME, Khanafer K, Hani EH, Yousef B. Numerical investigation of heat transfer watercooled roof in an electric arc furnace. J Therm Eng 2021;7:623-634. [CrossRef]

[21] Gandhewar VR, Bansod SV, Borade AB. Induction furnace-a review. Int J Eng Technol 2011;3:277-284.

[22] Miller DJ, Ruoff WH, Intermill AW, Thoman TR, Shao RL, Strong SL. U.S. Patent No. 6,724,803. Washington, DC: U.S. Patent and Trademark Office 2004.

[23] Dejaeghere L, Pierre T, Carin M, Masson PL, Courtois M. Design and development of an induction furnace to characterize molten metals at high temperatures. High Temperatures High Pressures 2018; 47:23-49.

[24] SI Units: Temperature. NIST Physical Measurements Laboratory. Available from: https://www.nist.gov/ $\mathrm{pml} /$ weights-and-measures/si-units-temperature [Accessed on 21 March, 2020]

[25] Regulations for obtaining use of the collective trade mark "Verace Pizza Napoletana" - (Vera Pizza Napoletana). Available from: https://www.pizzanapoletana.org [Accessed on 21 March, 2020]

[26] Mason K. Ten rules for energy efficient, cost effective brick firing-a guide for brick makers and fieldworkers. Appropriate Technology 2004;31:34-36.

[27] Hajizadeh R, Golbabaei F, Dehghan SF, Beheshti $\mathrm{MH}$, Jafari SM, Taheri F. Validating the heat stress indices for using in heavy work activities in hot and dry climates. J Res Health Sci 2016;16:90.

[28] DEA3500: Ambient Environment: Thermal Regulation notes. Cornell University Ergonomics Web. Available: http://ergo.human.cornell.edu/ studentdownloads/DEA3500notes/Thermal/thregnotes.html [Accessed on 12 March, 2020]

[29] Karim FA, Ozkaymak M, Ahmed S. Impacts of heat exposure on workers' health and performance at steel plant in Turkey. Eng Sci Technol 2018;21:745752. [CrossRef]

[30] Jafari MJ, Pirposhteh EA, Dehghan SF, Khodakarim S, Jafari M. Relationship between heat stress exposure and some immunological parameters among foundry workers. Int J Biometeorol 2020;64:853861. [CrossRef]

[31] BS EN ISO 8996:2004. Ergonomics of the thermal environment-determination of metabolic rate, 2004.

[32] Du Bois D, Du Bois EF. A formula to estimate the approximate surface area if height and weight be known. Arch Intern Med 1916;17:863-871. [CrossRef] 
[33] BS EN ISO 9920:2009. Ergonomics of the thermal environment-Estimation of thermal insulation and water vapor resistance of a clothing ensemble, 2009.

[34] Parsons KC. International standards for the assessment of the risk of thermal strain on clothed workers in hot environments. Ann Occup Hyg 1999;43:297308. [CrossRef]

[35] Ayyappan R, Sankar S, Raj KP, Balakrishnan K. Work-related heat stress concerns in automotive industries: a case study from Chennai, India. Glob Health Action 2009;2:2060. [CrossRef]

[36] Yang Y, Wei M, Hong S. Evaluation of occupation hot exposure in industrial workplaces in a subtropical country. Int J Occup Med Environ Health 2017;30:379-395. [CrossRef]

[37] Rabeiy RE. Evaluation of indoor heat stress on workers of bakeries at Assiut City, Egypt. Int J Environ Sci Technol 2019;16:2637-2642. [CrossRef]

[38] Zare S, Shirvan HE, Hemmatjo R, Nadri F, Jahani Y, Jamshidzadeh K, Paydar P. A comparison of the correlation between heat stress indices (UTCI, WBGT, WBDT, TSI) and physiological parameters of workers in Iran. Weather Clim Extremes 2019;26:1-7. [CrossRef]

[39] Parsons K. Human heat stress. Boca Rotan: CRC Press; 2019. [CrossRef]

[40] Lind AR, Bass DE. Optimal exposure time for development of acclimatization to heat. Fed Proc 1963;22:704-708.

[41] Gao C, Kuklane K, Östergren PO, Kjellstrom T. Occupational heat stress assessment and protective strategies in the context of climate change. Int J Biometeorol 2018;62:359-371. [CrossRef]

[42] BS EN ISO 7243:2017. Ergonomics of the thermal environment-assessment of heat stress using the WBGT (wet bulb globe temperature) index, 2017.

[43] BS EN ISO 9886: 2004. Ergonomics-Evaluation of Thermal Strain by Physiological Measurements. 2nd ed. 2004

[44] BS EN ISO 7933:2004. Hot environments - analytical determination and interpretation of thermal stress using calculation of required sweat rate, 2004.

[45] Parsons K. Heat stress standard ISO 7243 and its global application. Ind Health 2006;44:368-379. [CrossRef]

[46] Epstein Y, Moran DS. Thermal comfort and the heat stress indices. Ind Health 2006;44:388-398. [CrossRef]

[47] Moran DS, Shitzer A, Pandolf KB. A physiological strain index to evaluate heat stress. Am J Physiol 1998;275:129-134. [CrossRef]

[48] Moran DS. Stress evaluation by the physiological strain index (PSI). J Basic Clin Physiol Pharmacol 2000;11:403-23. [CrossRef]
[49] Thom EC. The discomfort index. Weatherwise 1959;12:57-61. [CrossRef]

[50] Tennenbaum J, Sohar E, Adar R, Gilat T. The Physiological Significance of the Cumulative Discomfort Index (Cum. DI). Harefuah 1961;60:315-319.

[51] Belding HS, Hatch TF. Index for evaluating heat stress in terms of resulting physiological strains. Heating, piping and air conditioning 1955;27:129-136.

[52] Havenith G, Fiala D. Thermal indices and thermophysiological modeling for heat stress. Compr Physiol 2011;6:255-302. [CrossRef]

[53] Masterton JM, Richardson FA. Humidex: a method of quantifying human discomfort due to excessive heat and humidity. Environment Canada. Atmospheric Environment, 1979.

[54] Rothfusz LP, Headquarters NSR. The heat index equation (or, more than you ever wanted to know about heat index). Fort Worth, Texas: National Oceanic and Atmospheric Administration, National Weather Service, Office of Meteorology, 1990.

[55] Steadman RG. The assessment of sultriness. Part I: a temperature-humidity index based on human physiology and clothing science. J Appl Meteorol 1979;18:861-873. [CrossRef]

[56] Miller VS, Bates GP. The thermal work limit is a simple reliable heat index for the protection of workers in thermally stressful environments. Annals of occupational hygiene 2007;51:553-561.

[57] Omer AH, Abdelaziz BJ, Ibrahim AM, Abdikarim YM, Rashid MN. Assessment of thermal exposure level among construction workers in UAE using WBGT, HSI and TWL indices. Ind Health 2020;58:170-181. [CrossRef]

[58] McArdle B, Dunham W, Holling HE, Ladell WSS, Scott JW, Thomson ML, et al. The prediction of the physiological effects of warm and hot environments. Med Res Council Rep 1947;47:391.

[59] Sharma MR, Ali S. Tropical summer index - a study of thermal comfort of Indian subjects. Build Environ 1986;21:11-24. [CrossRef]

[60] SP: 41-1987. Handbook on functional requirements of buildings (other than industrial buildings) (part 1-4), 1987.

[61] Bolghanabadi S, Ganjali A, Ghalehaskar S. Investigation of thermal exposure in traditional neyshabur bakeries using heat strain and physiological indices. MethodsX 2019;6:355-359. [CrossRef]

[62] Ramanathan NL. A new weighting system for mean surface temperature of the human body. J Appl Physiol 1964;19:531-533. [CrossRef]

[63] Oğulata RT. The effect of thermal insulation of clothing on human thermal comfort. Fibres Text East Eur 2007;15:61. 
[64] Djongyang N, Tchinda R, Njomo D. Thermal comfort: a review paper. Renew Sust Energy Rev 2010;14:2626-2640. [CrossRef]

[65] Alam MS, Muthiah A, Salve UR. A pilot study on thermal comfort in Indian Railway pantry car chefs. IOP Conf Series 2019;1240:1-9. [CrossRef]

[66] Pinto NM, Xavier AP, Amaral RT. Analysis of the thermal comfort model in an environment of metal mechanical branch. Work 2012;41:1606-1611. [CrossRef]

[67] Sugiono S, Novareza O, Fardian R. Thermal comfort study of plastics manufacturing industry in converting process. Przegląd Naukowy. Inżynieria i Kształtowanie Środowiska 2017;2:401-411. [CrossRef]

[68] Venugopal V, Krishnamoorthy M, Venkatesan V, Jaganathan V, Shanmugam R, Kanagaraj K, et al. Association between occupational heat stress and DNA damage in lymphocytes of workers exposed to hot working environments in a steel industry in Southern India. Temperature 2019;6:346-359. [CrossRef]

[69] Venugopal V, Latha PK, Shanmugam R, Krishnamoorthy M, Srinivasan K, Perumal K, et al. Risk of kidney stone among workers exposed to high occupational heat stress-A case study from southern Indian steel industry. Sci Total Environ 2020;137619:1-9. [CrossRef]

[70] Mohamed S, Srinavin K. Thermal environment effects on construction workers' productivity. Work Study 2002;51:297-302. [CrossRef]

[71] Kjellstrom T, Kovats RS, Lloyd SJ, Holt T, Tol RS. The direct impact of climate change on regional labor productivity. Arch Environ Occup Health 2009;64:217-227. [CrossRef]

[72] Ismail AR, Rani MRA, Makhbul ZKM, Nor MJM, Rahman MNA. A study of relationship between wbgt and relative humidity to worker performance. World Acad Sci Eng Technol 2009;51:209-214.

[73] Ma R, Zhong S, Morabito M, Hajat S, Xu Z, He Y, et al. Estimation of work-related injury and economic burden attributable to heat stress in Guangzhou, China. Sci Total Environ 2019;666:147-154. [CrossRef]

[74] Langkulsen U, Vichit-Vadakan N, Taptagaporn S. Health impact of climate change on occupational health and productivity in Thailand. Glob Health Action 2010;3:5607. [CrossRef]

[75] Beheshti MH, Boroumand E, Bahalgerdy B, Mehrafshan F, Zamani A. Performance loss among workers due to heat stress in high-temperature workplaces. J Occup Health Epidemiol 2015;4:116124. [CrossRef]

[76] Wu J, Fu M, Tong X, Qin YP. Heat stress evaluation at the working face in hot coal mines using an improved thermophysiological model. Int J Heat Technol 2017;35:67-74. [CrossRef]

[77] Kjellstrom T, Crowe J. Climate change, workplace heat exposure, and occupational health and productivity in Central America. Int J Occup Environ Health 2011;17:270-281. [CrossRef]

[78] Lee SW, Lee K, Lim B. Effects of climate changerelated heat stress on labor productivity in South Korea. Int J Biometeorol 2018;62:2119-2129. [CrossRef]

[79] Pogačar T, Casanueva A, Kozjek K, Ciuha U, Mekjavić IB, Bogataj LK, et al. The effect of hot days on occupational heat stress in the manufacturing industry: Implications for workers' well-being and productivity. Int J Biometeorol 2018;62:1251-1264. [CrossRef]

[80] Kjellstrom T, Maître N, Saget C, Otto M, Karimova T. Working on a warmer planet: The impact of heat stress on labour productivity and decent work. International Labour Office, 2019.

[81] Varghese BM, Hansen A, Bi P, Pisaniello D. Are workers at risk of occupational injuries due to heat exposure? A comprehensive literature review. Safe Sci 2018;110:380-392. [CrossRef]

[82] Li X, Chow KH, Zhu Y, Lin Y. Evaluating the impacts of high-temperature outdoor working environments on construction labor productivity in China: a case study of rebar workers. Build Environ 2016;95:4252. [CrossRef]

[83] Nunfam VF, Oosthuizen J, Adusei K, Van Etten EJ, Frimpong K. Perceptions of climate change and occupational heat stress risks and adaptation strategies of mining workers in Ghana. Science of the total environment 2019;657:365-378. [CrossRef]

[84] Sharma M, Kataria KK, Suri NM, Kant S. Monitoring respirable dust exposure in fettling work environment of a foundry: A proposed design intervention. IJSSE 2020;10:759-767. [CrossRef]

[85] Kataria KK, Sharma M, Kant S, Suri NM, Luthra S. Analyzing musculoskeletal risk prevalence among workers in developing countries: an analysis of small-scale cast-iron foundries in India. Arch Environ Occup Health 2021;15:1-8. [CrossRef]

[86] Bhowmick S. Assessing the impact of passive cooling on thermal comfort in LIG house using CFD. J Therm Eng 2019;5:414-421. [CrossRef]

[87] Anthony AS, Verma TN. Numerical analysis of natural convection in a heated room and its implication on thermal comfort. J Therm Eng 2021;7:37-53. [CrossRef]

[88] Khaleel AJ, Ahmed AQ, Dakkama HJ, Al-Shohani WA. Effect of exhaust layout on the indoor thermal comfort under harsh weather conditions. J Therm Eng 2021;7:148-160. [CrossRef] 
[89] Mohammadyan M, Sepehr P. Design of cool spot and assessment of its effect on WBGT index among furnace workers' position in Shimi Madani industry in Hamadan. Journal of Mazandaran University of Medical Sciences 2010;20:2-7.

[90] Kamar HM, Kamsah NB, Ghaleb FA, Alhamid MI. Enhancement of thermal comfort in a large space building. Alexandria Eng J 2019;58:49-65. [CrossRef]

[91] Alam MS, Salve UR. Enhancement of thermal comfort inside the kitchen of non-air conditioned railway pantry car. Int J Heat Technol 2021;39:275-291. [CrossRef]

[92] Hajiazimi E, Khavanin A, Solymanian A, Valipour F, Dehghan HA. Heat Stress Control in the Foundry Platform of a Steel Plant Tehran, Iran. J Health Syst Res 2011;13:866-874.
[93] Zare M, Dehghan H, Yazdanirad S, Khoshakhlagh AH. Comparison of the impact of an optimized ice cooling vest and a paraffin cooling vest on physiological and perceptual strain. Safe Health Work 2019;10:219-223. [CrossRef]

[94] Aryal A, Becerik-Gerber B. A comparative study of predicting individual thermal sensation and satisfaction using wrist-worn temperature sensor, thermal camera and ambient temperature sensor. Build Environ 2019;160:1-11. [CrossRef]

[95] Jha A, Tukkaraja P. Monitoring and assessment of underground climatic conditions using sensors and GIS tools. Int J Min Sci Technol 2020;30:495-499. [CrossRef] 